\title{
The history, progress, and future of global-scale geochemical mapping
}

\author{
David B. Smith ${ }^{1 *}$ \\ Alecos Demetriades ${ }^{2}$ \\ Patrice de Caritat ${ }^{3}$ \\ Xueqiu Wang ${ }^{4}$ \\ ${ }^{1}$ IUGS Commission on \\ Global Geochemical Baselines \\ 4170 Dover St \\ Wheat Ridge CO USA \\ 80033 \\ ${ }^{2}$ IUGS Commission on \\ Global Geochemical Baselines \\ Athens, Hellas \\ ${ }^{3}$ IUGS Commission on \\ Global Geochemical Baselines, \\ Canberra, Australia \\ ${ }^{4}$ UNESCO International Centre on \\ Global-Scale Geochemistry, \\ Langfang, China \\ * Corresponding author \\ dbsmith13@gmail.com
}

\begin{abstract}
RESUMO
Pesquisas geoquímicas de escala global ou de escala continental abrangem milhões de quilômetros quadrados da superfície da Terra, geralmente com uma densidade amostral muito baixa (1 ponto por 1.000 a $10.000 \mathrm{~km}^{2}$ ). Padrões geoquímicos produzidos a partir desses levantamentos de baixa densidade refletem processos que atuam na ampla escala de amostragem. Esses processos estão relacionados a vários fatores, incluindo a tectônica, clima, intemperismo, composição geoquímica e mineralógica do material original do solo, glaciação em escala continental, topografia, alteração e mineralização em escala regional e, em alguns casos, atividade humana. Um atlas geoquímico de múltiplos elementos da superfície da Terra baseado neste tipo de pesquisa tem sido um tópico de discussão entre os geoquímicos desde os anos 80. Nos últimos 15 anos, vários levantamentos geoquímicos em escala global foram conduzidos (Austrália, China, Europa, Índia, México, Estados Unidos da América) e os dados e mapas estão sendo usados como uma ferramenta para ajudar na gestão ambiental e de recursos. Em 2016, o estabelecimento da International Union of Geological Sciences (IUGS) Commission on Global Geochemical Baselines e da United Nations Educational, Scientific and Cultural Organization (UNESCO) International Centre for Global-Scale Geochemistry proporcionou um futuro promissor para a continuação do mapeamento geoquímico de escala global em outras partes do mundo, com o produto final sendo um banco de dados geoquímico global e um atlas derivado desse conjunto de dados.
\end{abstract}

Palavras-chave: mapeamento geoquímico, escala global, escala continental, levantamento geoquímico

\section{ABSTRACT}

Global-scale, or continental-scale, geochemical surveys cover millions of square kilometers of the Earth's surface generally at a very low sample density ( 1 site per 1000 to $10,000 \mathrm{~km}^{2}$ ). Geochemical patterns produced from these low-density surveys reflect processes that act at the broad scale of sampling. These processes are related to many factors including tectonics, climate, weathering, geochemical and mineralogical composition of the original soil parent material, continental-scale glaciation, topography, regional-scale alteration and mineralization, and in some cases, human activity. A multi-element geochemical atlas of the Earth's land surface based on this type of survey has been a topic of discussion among applied geochemists since the 1980s. Over the past 15 years, several global-scale geochemical surveys have been conducted (Australia, China, Europe, India, Mexico, United States of America) and the data and maps are being used as a tool to aid in environmental and resource management. In 2016, the establishment of both the International Union of Geological Sciences (IUGS) Commission on Global Geochemical Baselines and the United Nations Educational, Scientific and Cultural Organization (UNESCO) International Centre for Global-Scale Geochemistry has provided a hopeful future for continuing global-scale geochemical mapping in other parts of the world, with the ultimate product being a global geochemical database and atlas derived from this dataset.

Keywords: geochemical mapping, global scale, continental scale, geochemical survey 


\section{INTRODUCTION}

There is worldwide concern over the potentially damaging effects of chemicals in the environment on the health of humans, animals, and ecosystems (e.g., Nriagu, 1988; Plant et al., 2001, 2003, 2005; Skinner and Berger, 2003; Hester and Harrison, 2006; CDC, 2009; Lerner, 2012). Economic development and population growth are exacerbating such problems as land degradation and pollution from uncontrolled urbanization, industrialization, deforestation, intensive agricultural practices, and overexploitation of aquifers. These human activities, together with natural processes (e.g., weathering, erosion, flooding, volcanic eruptions) are having an impact on the geochemistry of the Earth's land surface and the sustainability of its life-support systems from the local to the global scale. There is also concern about the need to meet worldwide future demands for mineral and energy resources. This requires the discovery of new resources and their development in an environmentally responsible manner (Nickless et al., 2015; Ali et al., 2017).

Defining and understanding the current abundance and spatial distribution of chemicals in the Earth's surface or near-surface environmental compartments such as soil, sediment, surface and ground water, and vegetation, the so-called 'critical zone' (Brantley et al., 2007), are essential first steps in being able to recognize, quantify, and ultimately address natural or human-induced changes in the future. Dr. Mary Lou Zoback, former President of the Geological Society of America, stated the issue eloquently:

\section{'Documenting and understanding natural variability is a vexing topic in almost every environmental problem: How do we recognize and understand changes in natural systems if we don't understand the range of baseline levels?' (Zoback, 2001, p. 41).}

Systematic geochemical mapping is the best method available to assess and provide a baseline for monitoring changes in the levels of chemical elements at the Earth's surface (e.g., Reimann and Caritat, 2005). Geochemical maps have traditionally been valuable in addressing a range of environmental problems at the local to national scale, as well as for identifying potential mineral resources (e.g., Reimann and Caritat, 2005; Reimann et al., 2007; van Gaans et al., 2007; Rapant et al., 2008; Birke et al., 2016). Several decades of geochemical mapping by national geological surveys and related organizations throughout the world have resulted in a wealth of valuable information (Garrett et al., 2008). However, these data do not provide global coverage and cannot readily be applied to broader-scale regional or global studies because they have been generated by different sampling, sample preparation, and analytical methods. Part of the reason for this inconsistency is that there are no internationally accepted standards for geochemical surveys. To be useful and authoritative, particularly at the global scale, geochemical baselines must be derived from data generated according to well-defined protocols that are applicable across a wide range of geomorphic landscapes, climatic zones, and ecological regions. It is possible that such incompatible data could be more effectively used if normalized to a reference dataset; that is, data generated from a worldwide suite of geochemical samples collected, prepared, and analyzed using a universally consistent set of protocols (Salminen, Tarvainen et al., 1998).

Establishing a global-scale geochemical database covering the entire land surface of the Earth and based on consistent, standardized sampling, sample preparation, analytical methods, and quality control protocols has been a muchdiscussed topic among applied geochemists since at least the 1980s. The purpose of this paper is to (1) summarize the history and evolution of the global-scale geochemical baselines effort, (2) provide information about ongoing activities that make obtaining a global-scale geochemical database more likely than ever before, and (3) show examples of geochemical and mineralogical maps produced from low-sampling-density, global-scale mapping projects that illustrate the broad-scale processes that cause the observed map patterns.

\section{WHAT DO WE MEAN BY GLOBAL-SCALE GEOCHEMICAL MAPPING?}

It is important in this discussion to first establish exactly what is meant by global-scale geochemical mapping. Global-scale, or continental-scale, geochemical surveys cover millions of square kilometers of the Earth's land surface generally at a very low sample density (1 site per 1000 to $10,000 \mathrm{~km}^{2}$ ). Although globalscale geochemistry can be conducted at high 
densities (e.g., 1 site per $\mathrm{km}^{2}$ ), much lower densities are normally required to control the costs of mapping such huge areas. In this paper, the term 'global-scale geochemistry' refers to such low-sampling-density geochemical mapping programs covering huge areas of the Earth's land surface.

\section{HISTORY AND EVOLUTION OF GLOBAL-SCALE GEOCHEMICAL MAPPING}

\subsection{5-1984: THE FIRST CONTINENTAL-SCALE GEOCHEMICAL MAPPING PROJECTS}

The first continental-scale geochemical mapping project was conducted by the U.S. Geological Survey (USGS) under the leadership of Hansford T. Shacklette. From the mid-1960s through the early 1980s, Shacklette and colleagues collected samples of soil and other regolith material from 1323 sites in the conterminous United States of America representing a sample density of approximately 1 site per $6000 \mathrm{~km}^{2}$. The samples were analyzed for 50 elements by a variety of methods, all of which provided total elemental concentrations. However, 30 of the elements were determined by a method that only gave semi-quantitative results (Smith et al., 2013a). The raw data from the study were published by Boerngen and Shacklette (1981); an interpretive report, including statistical summary tables and black-and-white point-symbol geochemical maps, was published by Shacklette and Boerngen (1984). In 2001, more modern mapping methods using a 'Bootstrap' estimate of the moving weighted median were utilized to produce new, full-color, geochemical maps for 22 elements (Gustavsson et al., 2001).

The first multi-national continental-scale geochemical project utilizing multiple sample media was the Nordkalott Project (Geochemical Survey of Northern Fennoscandia), conducted north of the $66^{\text {th }}$ parallel by the Geological Surveys of Norway, Sweden, Greenland, and Finland. The project started in 1980 and was completed in 1986 (Bølviken et al., 1986), with the collection and multi-element analysis of till, stream sediment, stream organic matter, and stream moss samples.

\subsection{4: INITIATION OF THE CONCEPT OF A WORLD GEOCHEMICAL MAP}

The concept of a world radiometric geochemical map was conceived at a 1984 workshop organized in Sweden by the International Atomic Energy Agency (IAEA). Most of the discussion was focused on mapping the naturally occurring radioactive elements $(\mathrm{K}$,
$\mathrm{U}$, and $\mathrm{Th}$ ) because these elements fall under the mandate of the IAEA. However, the advocates of such a global project recognized the need for geochemical surveys that include a much more comprehensive set of elements.

\subsection{6-1993: PROPOSAL AND PILOT STUDY FOR THE CONTINENTAL-SCALE GEOCHEMICAL MAPPING OF EUROPE}

A pivotal event that catalyzed interest in global-scale geochemistry was the Chernobyl accident in Ukraine on 26 April 1986. The accident resulted in large quantities of radioactive substances being released into the atmosphere for about 10 days. Most of the released material was deposited nearby as dust and debris, but the lighter material was carried by wind over Ukraine, Belarus, Russia, and to some extent over Scandinavia and Europe. Applied geochemists and other scientists quickly recognized that no harmonized, world-wide geochemical baseline data existed to assess the impact of such humancaused accidents that affect a whole continent or, possibly, the entire globe.

This missing and vital information was discussed on 21-22 May 1986 in Trondheim,
Norway, during the inaugural meeting of the Working Group on Regional Geochemical Mapping of the then Western European Geological Surveys (WEGS; later renamed the Forum of European Geological Surveys (FOREGS) and presently called EuroGeoSurveys), under the chairmanship of Bjørn Bølviken of the Geological Survey of Norway. At this meeting, the results of the then unpublished Nordkalott Project (Bølviken et al., 1986) and the first regional overbank sediment survey of Norway were presented and discussed. The outcome of the meeting was the submission of a proposal to the WEGS Directors for the multi-media sampling of surface water, ground water, topsoil, subsoil (C horizon), and overbank sediment throughout the WEGS countries. In 
1988, a two-year pilot project was approved to test the sampling methodology and, especially, the use of overbank (or floodplain) sediment as a harmonized sampling medium applicable to different morphoclimatic environments (Ottesen et al., 1989). The Pilot Project Report (Demetriades et al., 1990), and Project Proposal (Bølviken et al., 1990) were submitted to the WEGS Directors in 1990. In 1993, the final report and a project proposal were submitted to the Directors of FOREGS (Bølviken et al., 1993, 1996). The proposal was for the geochemical mapping of Europe by sampling top and bottom overbank sediment and stream sediment from catchments with an area between 60 and $600 \mathrm{~km}^{2}$ at an average sampling density of 1 site per 500 $\mathrm{km}^{2}$.

\subsection{7-1992: INTERNATIONAL GEOCHEMICAL MAPPING PROJECT (IGCP 259)}

The Chernobyl accident generated interest in the applied geochemistry community for the compilation of a global radiometric map. This was discussed at the inaugural meeting of the WEGS Working Group on Regional Geochemical Mapping in 1986, and the group considered a joint proposal for an 'International Geochemical Mapping' project to be submitted to the International Geological Correlation Programme (IGCP), presently the International Geoscience Programme. IGCP is a cooperative enterprise of the United Nations Educational, Scientific and Cultural Organization (UNESCO) and the International Union of Geological Sciences (IUGS).

During the $12^{\text {th }}$ International Geochemical Exploration Symposium in Orléans, France, in 1987, the proposal for International Geochemical Mapping was discussed at length by a steering group comprised of Arthur G. Darnley (Canada), Alf Bjørklund (Finland), Bjørn Bølviken (Norway), P.V. Koval (Russia), E. Wilhelm
(France), F. Mrna (Czechia) and Xie Xuejing (China) with a decision to submit to UNESCO a proposal for international geochemical mapping under the auspices of IGCP. The proposal was formally supported by the International Association of Geochemistry and Cosmochemistry (presently the International Association of GeoChemistry, IAGC), and the Association of Exploration Geochemists (presently the Association of Applied Geochemists, AAG).

The proposal was endorsed by IGCP in 1988 as the International Geochemical Mapping Project (IGCP 259). IGCP 259 ran until 1992 under the leadership of Arthur G. Darnley of the Geological Survey of Canada. The objectives of this project were to conduct a comprehensive review of methods being used at that time for regional-, national-, and international-scale geochemical mapping studies and to develop recommendations for producing a global-scale geochemical database.

\subsection{3-1997: GLOBAL GEOCHEMICAL BASELINES PROJECT (IGCP 360)}

From 1993 to 1997, IGCP 259 continued under IGCP as Project 360, Global Geochemical Baselines (Darnley, 1995, 1997; Smith et al., 2012), with Arthur G. Darley continuing as leader. The project's final report, A global geochemical database for environmental and resource management (Darnley et al., 1995), was published by the Earth Sciences Division of UNESCO with financial support from IUGS, IAGC, AAG, IAEA, and the Royal Society. This report, known in the geochemical mapping community as the Blue Book because of the color of its cover, contains a wealth of information about geochemical mapping at all scales and was so popular that a second printing was required in 1996.

To begin global geochemical mapping, the report proposed that various sampling media (stream sediment, soil, humus, overbank sediments, surface water) be collected worldwide based on a global geochemical reference network
(GRN), which covers the Earth's land surface with about 5000 grid cells of approximately $160 \mathrm{x}$ $160 \mathrm{~km}$ in size (Fig. 1). The GRN has its origin on the equator at the Greenwich meridian. Grid cells of the GRN are defined by two parallels of latitude $1.5^{\circ}$ apart and by meridians spaced in successive latitudinal bands to maintain a constant area of 25,600 $\mathrm{km}^{2}$ (Darnley, 1997).

The ensuing database and samples would serve several purposes:

- provide data from which a global-scale geochemical atlas may be prepared;

- provide an archive of samples for use by future researchers;

- provide documentation of the composition of a variety of surficial materials at locations with a relatively uniform spatial distribution over the land surface of the Earth; 
- provide a supply of locally relevant standard reference materials for use in more detailed geochemical surveys in the region of origin;

- provide reference points for normalizing national-scale geochemical databases; and

- provide sites for recurrent monitoring in the future to facilitate the recognition and quantification of change caused by natural processes or anthropogenic activities.

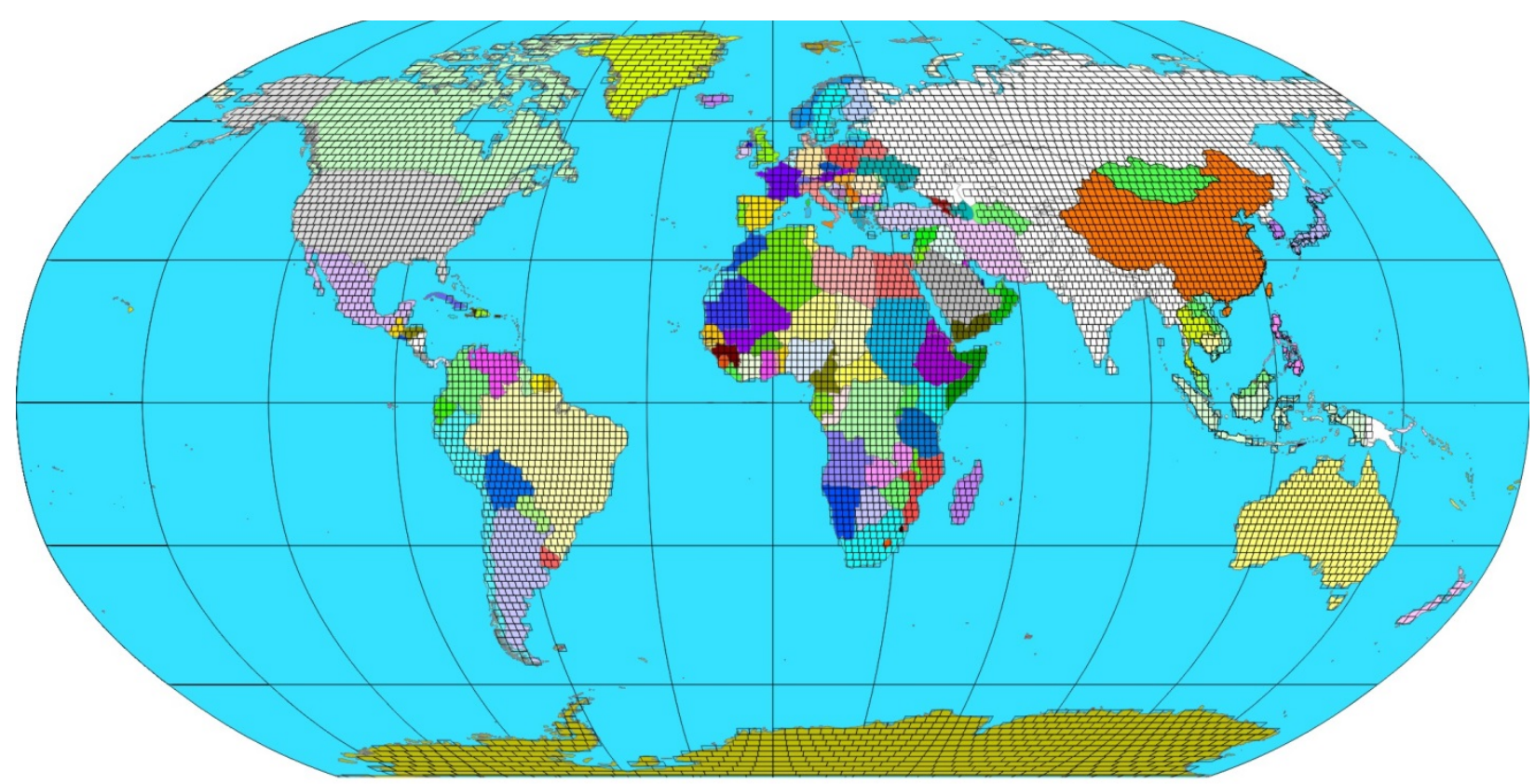

Figure 1 Map showing the $160 \times 160 \mathrm{~km}$ grid cells of the global geochemical reference network (GRN).

The Darnley et al. (1995) report outlined several basic requirements that should be followed for establishing a global geochemical database of long-term value:

- commonly available representative sample media, collected in a standardized manner;

- continuity of data across different landscape types;

- adequate quantities of the sample media for future reference and research requirements;

- analytical data for all elements of environmental or economic significance;

- the lowest possible detection limits for all elements; and

- strict quality control at every stage of the process.

In 1996, the United Nations Committee on Natural Resources, in its Resolution 3/5, recognized the Blue Book as 'a comprehensive blueprint' for an effort to establish the natural chemical variability of the land surface as part of a proposed global land monitoring program and officially endorsed the establishment of a global geochemical database. Unfortunately for globalscale geochemical mapping, the Committee on Natural Resources was merged with two other committees in 1998 and priorities shifted to water and energy resources.

Darnley et al. (1995, p.87) anticipated in their report that the progress at the international scale would be slow and they proposed the need for a permanent organization to coordinate the work:

'Because of the number of organisational and technical steps involved, it seems highly unlikely that any group of scientists convened under a non-government organisation, however enthusiastic, could sustain or manage an international sampling activity (other than as a small test project in a sympathetic jurisdiction) over the period of time required for completion.... Assuming the importance of the geochemical information to be obtained is recognised by the international scientific community, there is a clear need for a single permanent agency to accept 
formal responsibility for securing funds, managing and coordinating these activities according to scientific guidelines determined by an external advisory committee.... A World Geochemical Data Centre is required as a focal point, responsible for long term data management. This centre must be closely linked to regional centres, which could coordinate the periodic monitoring of reference sample sites in the context of global change and other environmental issues.'

During this time, Xie Xuejing (Institute of
Geophysical and Geochemical Exploration, China) tested the feasibility of floodplain sediment for global-scale geochemical mapping by using China as the pilot survey area (Xie and Cheng, 1997). This was the EGMON (Environmental Geochemical Monitoring Network) project. During 1994-1996, top (5-25 $\mathrm{cm})$ and bottom $(80-120 \mathrm{~cm})$ floodplain sediment samples were taken from 529 sites throughout China representing a density of approximately 1 site per $18,000 \mathrm{~km}^{2}$. The similarity of geochemical maps produced from this ultra-low-density study with those produced from data collected at a much higher density was noted by Yao et al. (2014) among others.

\subsection{7: ESTABLISHMENT OF IUGS/IAGC TASK GROUP ON GLOBAL GEOCHEMICAL BASELINES}

Following completion of the two IGCP projects, IUGS, in collaboration with IAGC, established the Task Group on Global Geochemical Baselines (Reeder, 2007; Reeder et al., 2002; Smith et al., 2012, 2017) under the leadership of David B. Smith (USA, 1997-2016), Jane Plant (UK, 1997-2008), and Xueqiu Wang (China, 2008-2016). The Task Group's main objective for this third phase was to encourage and facilitate the population of the GRN worldwide through application of the sampling, sample preparation, analytical and data management protocols established in the earlier phases of the project. Because the Task Group was not a funding organization, its activities were limited to:

- developing partnerships with countries conducting broad-scale geochemical mapping studies;

- providing consultation and training in the form of workshops and short courses;

- organizing periodic international symposia to foster communication among the geochemical mapping community;

- developing criteria for certifying those projects that are acceptable in a global geochemical database;

- acting as a repository for data collected by those projects meeting the standards for harmonization;

- preparing complete metadata for the certified projects; and

- preparing, ultimately, a global geochemical database.

\subsection{7-2006: FOREGS GEOCHEMICAL BASELINE MAPPING PROJECT}

Directly after the publication in 1995 of the IGCP 259 final report (Darnley et al., 1995) and the recommendations of the FOREGS Geochemistry Task Group (Plant et al., 1996), the Directors of FOREGS approved the first multinational continental-scale geochemical mapping of Europe, according to IGCP 259 specifications. The project, under the chairmanship of Reijo Salminen (Geological Survey of Finland), started in June 1997 with the development of sampling methods and writing of a field sampling manual, which was published in 1998 (Salminen, Tarvainen et al., 1998), and ended with the publication of the two-volume Geochemical Atlas of Europe (Salminen et al., 2005; De Vos, Tarvainen et al., 2006). Twenty-six European countries participated in the project and collected stream sediment, stream water, topsoil, subsoil, humus and floodplain sediment samples at an average sampling density of 1 site per $4600 \mathrm{~km}^{2}$.

\subsection{3-2015: NORTH AMERICAN SOIL GEOCHEMICAL LANDSCAPES PROJECT}

The North American Soil Geochemical Landscapes Project was initiated in 2003 with the United States of America (USA), Mexico, and Canada collaborating with the intent of collecting soil samples at a density of 1 site per $1600 \mathrm{~km}^{2}$ throughout these three countries. Canada dropped out of the project in 2009, but the USA and Mexico completed sampling and chemical analysis over an area of about 9.64 million $\mathrm{km}^{2}$. The results from the USA are published in Smith 
et al. (2013b, 2014) with additional discussion and interpretation in Woodruff et al. (2015) and Grunsky et al. (2018). At present, the data from Mexico are not publicly available.

In the conterminous USA, soil samples were collected from 4857 sites across all physiographic provinces $\left(\approx 8\right.$ million $\left.\mathrm{km}^{2}\right)$ during 2007-2010. The sampling protocol represented a combination of depth-based and horizon-based sampling. Ideally, the following sample types were collected at each site: (1) soil from a depth of 0 to $5 \mathrm{~cm}$, regardless of what horizon(s) this might represent;
(2) a composite of the soil A horizon, and (3) a deeper sample from the soil $\mathrm{C}$ horizon or, if the top of the $\mathrm{C}$ horizon was at a depth greater than $1 \mathrm{~m}$, a sample from a depth of approximately 80 $100 \mathrm{~cm}$ was taken. The $<2-\mathrm{mm}$ fraction of each sample was ground in a ceramic mill and analyzed for a suite of 45 major and trace elements by methods that yield total or near-total elemental concentrations. The major mineralogical components in the samples from the soil A and $\mathrm{C}$ horizons were determined by X-ray diffractometry using a Rietveld refinement technique.

\subsection{4-2008: NATIONAL-SCALE GEOCHEMICAL MAPPING IN INDIA}

In 2004, the National Geophysical Research Institute in Hyderabad, India, initiated a project to map the soil geochemistry of India (3.29 million $\mathrm{km}^{2}$ ). Sampling was conducted based on the GRN cells with 544 top soils $(5-20 \mathrm{~cm})$ and 469 bottom soils $(70-80 \mathrm{~cm})$ collected in 115 out of the 122
GRN cells covering India. The $<0.5$-mm fraction of the soil samples was analyzed for 24 major and trace elements by X-ray fluorescence spectrometry. Unfortunately, the data are not publicly available, and, to our knowledge, no interpretive products have been published.

\subsection{7-2011: NATIONAL GEOCHEMICAL SURVEY OF AUSTRALIA (NGSA)}

The National Geochemical Survey of Australia (NGSA) was initiated in 2007 as a collaboration between the Federal and the State/Northern Territory geological surveys to deliver Australia's first continental-scale geochemical dataset and atlas. The chosen sampling medium was catchment outlet sediment (similar to floodplain sediment but recognizing the presence of an aeolian contribution in places) collected from two depths: $0-10 \mathrm{~cm}$ (top outlet sediment) and, on average, $60-80 \mathrm{~cm}$ (bottom outlet sediment). Thus, 2630 samples (including $\approx 10 \%$ field duplicates) were collected near the outlet of 1186 large catchments, covering nearly 6.2 million $\mathrm{km}^{2}$ at an average sampling density of 1 site per 5200 $\mathrm{km}^{2}$. The sediment samples were air-dried and sieved to a coarse $(<2 \mathrm{~mm})$ and a fine $(<0.075$ $\mathrm{mm})$ grain-size fraction, which were analyzed by several methods to yield total element concentrations (mostly by X-ray fluorescence spectrometry and inductively coupled plasmamass spectrometry), aqua regia soluble element concentrations, and Mobile Metal Ion ${ }^{\circledR}$ extractable element concentrations. Additional properties, such as field and lab $\mathrm{pH}$, electrical conductivity, soil color, and visible-near infrared reflectance spectra were also determined. A comprehensive quality control program was implemented from fieldwork planning to reporting phases of the project.

The data and several reports are freely available from http://www.ga.gov.au/ngsa (accessed 18 April 2018), and the atlas was published by Caritat and Cooper (2011). A number of peer-reviewed journal articles have been published on the NGSA data, including a compositional data compliant principal component analysis of part of this dataset by Caritat and Grunsky (2013), a discussion of the background variation and threshold values for 59 chemical elements in Australian surface soil (Reimann and Caritat, 2017), a self-organizing map method integrating geological and geophysical data with the geochemical dataset (Cracknell and Caritat, 2017), and a prospectivity analysis spanning the regional to continental scales for porphyry copper-gold systems (Caritat et al., 2017). Caritat and Cooper (2016) recently reviewed the considerable body of research todate on the NGSA dataset.

\subsection{8-2014: CHINA GEOCHEMICAL BASELINES PROJECT}

The China Geochemical Baselines Project (CGB) was formally launched in 2008 with the goal to provide high-quality concentration data and distribution maps for 76 chemical elements over the whole of China (9.6 million $\mathrm{km}^{2}$ ) (Wang et al., 2010). Sampling was based on 1500 CGB grid cells approximately $80 \times 80 \mathrm{~km}$ in size (equivalent to one-quarter of a GRN cell). Sampling sites were selected from at least two large drainage basins in each CGB cell. Sampling 
media consisted of floodplain sediment or alluvial soil in plains and hilly landscape terrains, overbank sediment in mountainous terrains, and catchment-basin sediment or lake sediment in desert and semi-desert terrains. Top samples were generally collected from the soil A horizon at a depth of $0-25 \mathrm{~cm}$, or from the surface to the bottom of the A horizon if the thickness of the A horizon was less than $25 \mathrm{~cm}$. Deep samples were generally collected from a depth of more than 100 $\mathrm{cm}$ if the top of the soil $\mathrm{C}$ horizon was deeper than $100 \mathrm{~cm}$ or from the deepest part of $\mathrm{C}$ horizon if the soil horizon did not extend to a depth of 100

\subsection{8-2014: GEMAS PROJECT}

During 2008-2009, the EuroGeoSurveys Geochemistry Expert Group, in collaboration with Eurometaux, collected 2108 samples of agricultural land soil and 2023 samples of grazing land soil representing a sampling density of approximately 1 site per $2500 \mathrm{~km}^{2}$ throughout 33 European countries. This project was called 'Geochemical Mapping of Agricultural and Grazing Land Soil in Europe', or GEMAS. Sampling protocols were dictated by the REACH (Registration, Evaluation, Authorisation and Restriction of Chemicals) regulation, which stated that soil samples from agricultural land must be

\subsection{6: TWO IMPORTANT STEPS FORWARD}

In 2016, two events occurred that have the potential to greatly advance the cause of globalscale geochemical mapping. In May 2016, the UNESCO International Centre for Global-Scale Geochemistry (ICGG) opened in Langfang, $\mathrm{cm}$. Complete details of the sampling methodology are given in Wang and the CGB Sampling Team (2015). A total of 6617 samples from 3382 sites were collected, corresponding to a density of approximately one sample site per 3000 $\mathrm{km}^{2}$ (Wang and the CGB Sampling Team, 2015). The $<2$-mm fraction of each sample was ground to $<74 \mu \mathrm{m}$ and analyzed for 76 elements (Zhang et al., 2012). A portion of the data is available at http://www.globalgeochemistry.com/en/main.php ?action $=$ displaybody\&s=107\&pid=144 (accessed 20 April 2018).

collected from a depth of $0-20 \mathrm{~cm}$ and soil samples from grazing land must be collected from depth of $0-10 \mathrm{~cm}$. All samples were analyzed for 52 elements following an aqua regia extraction and 41 elements by X-ray fluorescence spectrometry. The results were published in the two-volume Chemistry of Europe's Agricultural Soils (Reimann et al., 2014a,b). Many papers based on this dataset have been published in the peer-reviewed literature. A listing of these publications is available on the GEMAS website (http://gemas.geolba.ac.at/Publications_GEMAS.h tm, accessed 20 April 2018).

\subsubsection{IUGS COMMISSION ON GLOBAL GEOCHEMICAL BASELINES}

According to IUGS By Laws, one of the primary objectives of IUGS Commissions is to 'coordinate long-term international cooperative investigations to establish standards in appropriate fields.' Accordingly, the long-term mission of the CGGB is to work with applied geoscientists throughout the world to standardize methods for conducting global-scale geochemical baseline studies.

The new IUGS Commission is led by a fourperson steering committee. As of this writing (May 2018), the members of the Steering
China. This was followed in August by IUGS elevating the status of the Task Group on Global Geochemical Baselines to that of an IUGS Commission on Global Geochemical Baselines (CGGB).

\subsubsection{UNESCO INTERNATIONAL CENTRE ON GLOBAL-SCALE GEOCHEMISTRY}

Although much progress was made during the tenure of the IUGS Task Group on Global
Committee are: David B. Smith, $1^{\text {st }}$ Co-Chair (U.S. Geological Survey, retired), Xueqiu Wang, $2^{\text {nd }}$ Co-Chair (Institute of Geophysical and Geochemical Exploration and ICGG, China), Alecos Demetriades, Treasurer (Institute of Geology and Mineral Exploration, Hellas, retired), and Patrice de Caritat, Secretary (Geoscience Australia).

More information about the activities of the CGGB can be found on its website at http://www.globalgeochemicalbaselines.eu/ (acessed 20 April 2018). 
impossible for such an ad hoc group of scientists, working under a non-government organization, to sustain and manage an international sampling effort to establish a global geochemical database. This was the impetus for the establishment of the new Centre.

The ICGG is a 'Category 2' research centre operating under the auspices of UNESCO. Though not legally part of UNESCO, the Centre is associated with UNESCO through formal arrangements between UNESCO and the People's Republic of China. The long-term mission of the ICGG includes: (1) fostering knowledge and technology of global-scale geochemistry, (2) documenting the global concentration and distribution of chemical elements at the Earth's surface, (3) training scientists in global-scale geochemical mapping methods and providing technical assistance to developing countries, and (4) developing a bridge from the scientific community to both decision makers and the general public in the field of global-scale geochemistry.

As of this writing (May, 2018) the ICGG is led by a Director (Peng Xuanming), a Deputy
Director (Hao Guojie), and an Executive Scientific Director (Xueqiu Wang). The functioning of the Centre is overseen by an international Governing Board and technical guidance is provided by a Scientific Committee comprised of geoscientists from around the world.

The ICGG has established a global cooperative network. In 2016, for example, the ICGG financially and technically supported several countries (i.e., Mongolia, Russia, Laos, Cambodia, Indonesia, Papua New Guinea, Iran, Turkey, Mexico, Peru, Madagascar, and Pakistan) to carry out global geochemical baselines mapping.

Although the missions of the ICGG and CGGB overlap considerably, there is a notable difference. The CGGB is tasked with establishing standards for global-scale geochemical baselines mapping, whereas the ICGG is tasked with implementing these standards through international collaborative agreements with participating countries. The ICGG and the CGGB work together to provide training in geochemical mapping techniques, particularly for the developing countries.

\section{EXAMPLES OF PROCESSES REVEALED BY GLOBAL-SCALE GEOCHEMICAL MAPPING}

Data generated by global-scale geochemical mapping projects produce map patterns that reflect processes acting across hundreds to thousands of $\mathrm{km}^{2}$ (e.g., Caritat et al., 2018). These processes may be related to factors such as climate and weathering, continental-scale glaciation, topography, regional-scale alteration and mineralization, and, in some cases, human activities. Maps produced by the USGS Soil Geochemical Landscapes of the Conterminous United States (SGL) Project will be used hereafter to provide examples of the types of patterns observed in such global-scale mapping projects and of the processes that cause the observed patterns (Fig. 2). The sampling and analytical protocols for this project were summarized previously in this paper in the section titled '20032015: North American Soil Geochemical Landscapes Project.'

Having the mineralogy to accompany the geochemical data is a major asset in the interpretation of the geochemical patterns. Maps showing predicted element and mineral concentrations were interpolated from the actual data points published in Smith et al. (2013b) by an inverse distance weighted (IDW) technique using ArcGIS software. The IDW method used predicts unique concentration values for an array of 444$\mathrm{km}^{2}$ grid cells covering the conterminous USA (approximately 8 million $\mathrm{km}^{2}$ ). A weighted average of concentration values for all data points within $75 \mathrm{~km}$ of the center of each grid cell is calculated. The closer a sample point is to the cell being estimated, the more influence that point has in the averaging process. The relative influence of closer and more distant points can be adjusted by varying a power function. For all the maps, the default value of 2 was used, which assigns relatively high significance to the nearest data points. Details of the map generation and a complete set of geochemical and mineralogical maps are published in Smith et al. (2014).

The interaction of climate with the minerals of the underlying soil parent material is a major controlling factor on the geochemical patterns observed in this study. Ideally, soil geochemistry will reflect underlying parent material and processes associated with the modification of those parent materials through physical and chemical weathering, the action of soil microbes, and chemical reactions in the soil profile. All these factors are functions, to some extent, of climate.

The parameter used here to represent climate is average annual precipitation (Fig. 3). A broad, relatively uniform, gradient in average annual precipitation extends across nearly two thirds of the USA from low precipitation immediately east 
of the Rocky Mountains (areas 15, 17, and 18 in Fig. 2) to higher precipitation in the east and south-east. Annual precipitation varies by about a factor of 5 along this gradient (Fig. 3). A second, much sharper, gradient in the north-western United States separates areas of very high rainfall along the west coast from a drier climate inland. The boundary between these two climate regimes lies along the eastern slope of the Cascade Range and the Sierra Nevada Mountains (area 22 in Fig. 2). Annual precipitation varies by a factor of ten between the western (wetter) and eastern (drier) flanks of these ranges. Both the broad national and the more local west coast precipitation gradients are strongly expressed in soil composition as discussed below.

One of the major changes in soil geochemistry and mineralogy across the conterminous USA is caused by the increasing weathering of feldspar minerals from west to east along the gradient of increasing precipitation from the Rocky Mountains to the Atlantic coast in the east and southeast. Figure 4 shows the distribution of total feldspar (total plagioclase + total potassium feldspar) in the soil A horizon. These feldspar minerals are susceptible to weathering in soil. With time and a sufficiently humid climate, they will break down to form the clay mineral kaolinite $\left[\mathrm{Al}_{2} \mathrm{Si}_{2} \mathrm{O}_{5}(\mathrm{OH})_{4}\right]$, while releasing $\mathrm{Na}, \mathrm{K}$, and $\mathrm{Ca}$, which are relatively mobile and tend to leach out of the soil profile. Total feldspar, prevalent in elevated concentrations in soils formed on igneous and metamorphic rocks in the western USA (Fig. 4), decreases in concentration toward the east and south-east where the feldspar minerals have been destroyed by weathering and converted to clay minerals in this much wetter climate.

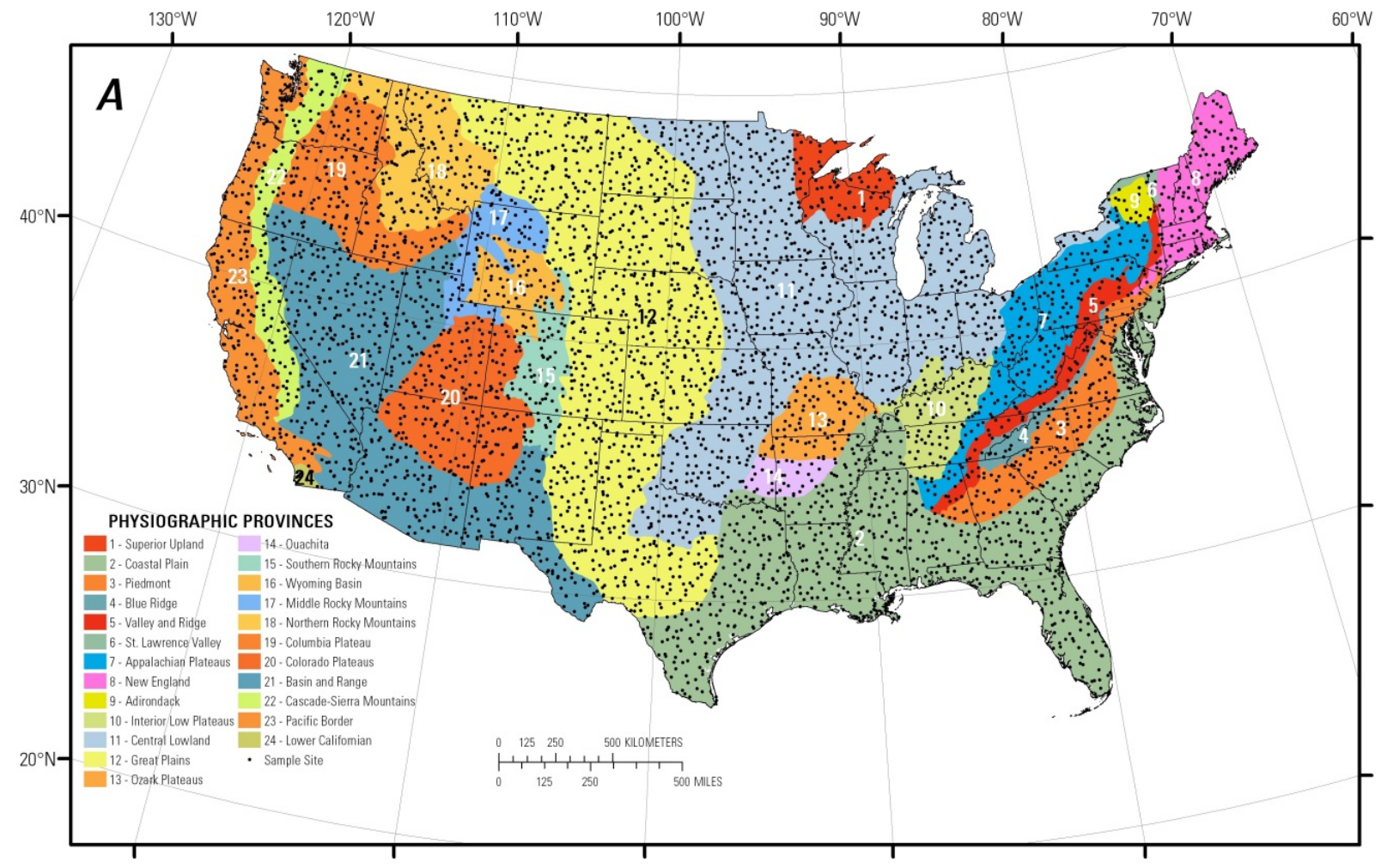

Figure 2

Map showing the distribution of soil sampling sites (small black dots) from the USGS Soil Geochemical Landscapes of the Conterminous United States Project. Also shown on the map are the physiographic provinces of the United States (Fenneman and Johnson, 1946). 


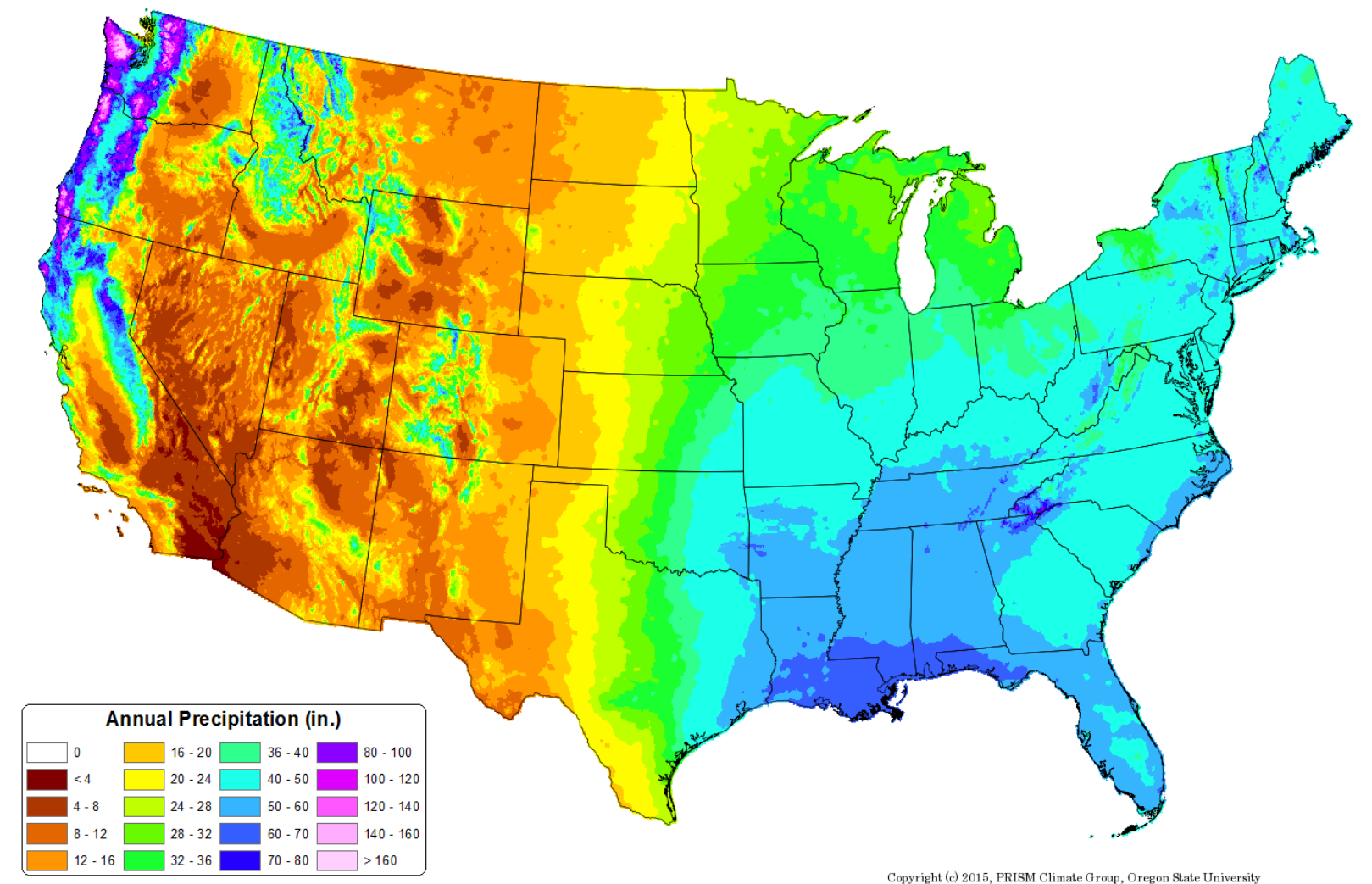

Figure 3

Map of average annual precipitation, in inches $(1 \mathrm{inch}=25.4 \mathrm{~mm}$ ), for the conterminous United States based on data from 1981 to 2010 (http://prism.oregonstate.edu/normals/, accessed 20 April 2018).

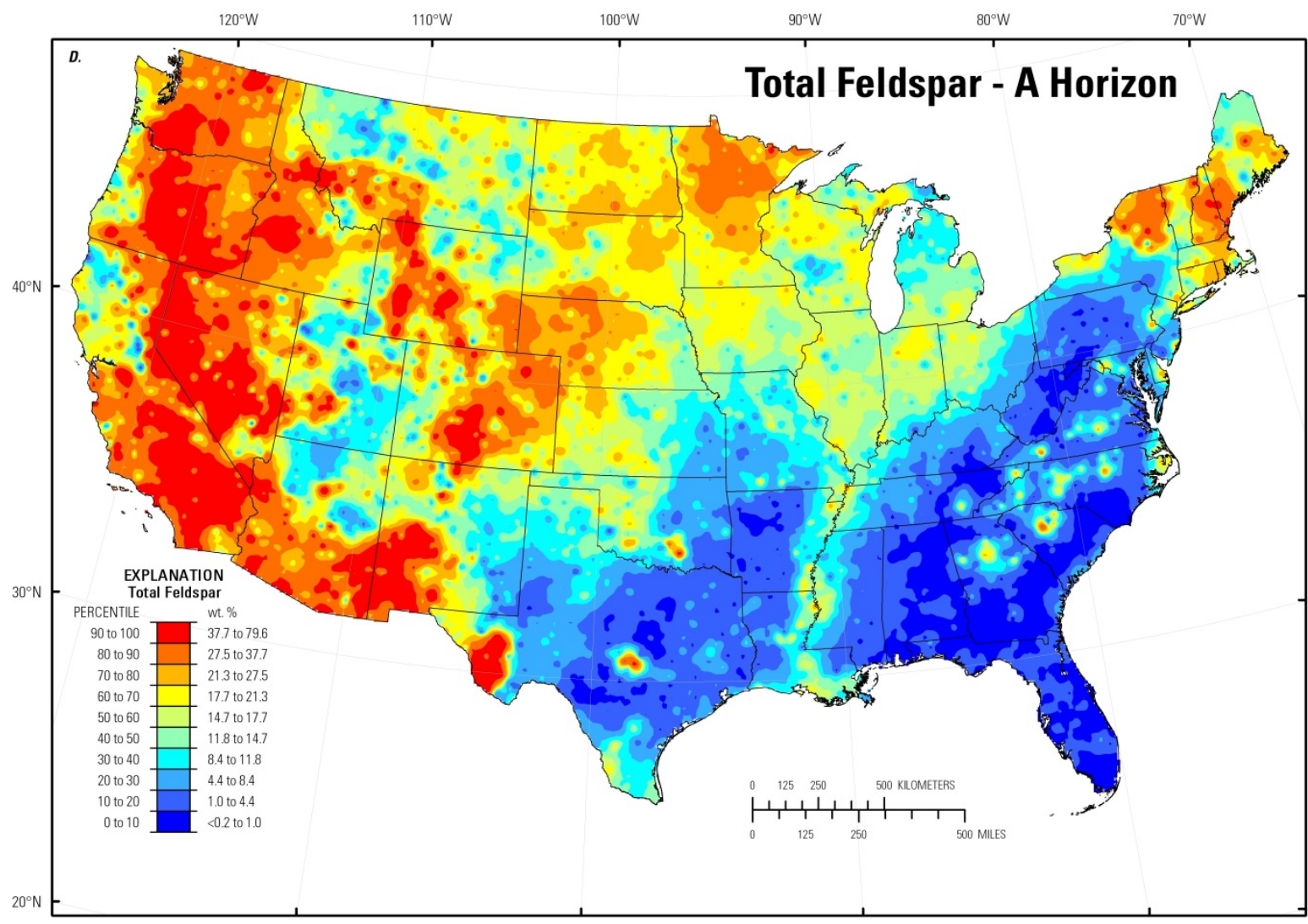

Figure 4 
This relationship between decreasing feldspar content with increasing precipitation is perhaps even more distinct when visualized using data from the pilot studies for the SGL Project (Smith et al., 2009). These pilot studies collected soil samples along two continental-scale transects (Fig. 5). One of the transects trends west-to-east along the $38^{\text {th }}$ parallel of latitude from the Pacific coast of the USA north of San Francisco, California, to the Atlantic coast along the Virginia shore. This transect was located to cross multiple climatic, topographic, physiographic, land-use, geologic, pedologic, and ecological boundaries. Figure 6 shows a relatively linear eastward decrease in total feldspar from about $30 \mathrm{wt} \%$ just east of the Rocky Mountains to about $2 \mathrm{wt} \%$ at the Atlantic Coast, with $r^{2}=0.74$ for this linear trend. Figure 7 shows a corresponding linear increase $\left(\mathrm{r}^{2}\right.$ $=0.78)$ in average annual precipitation along this same portion of the transect.

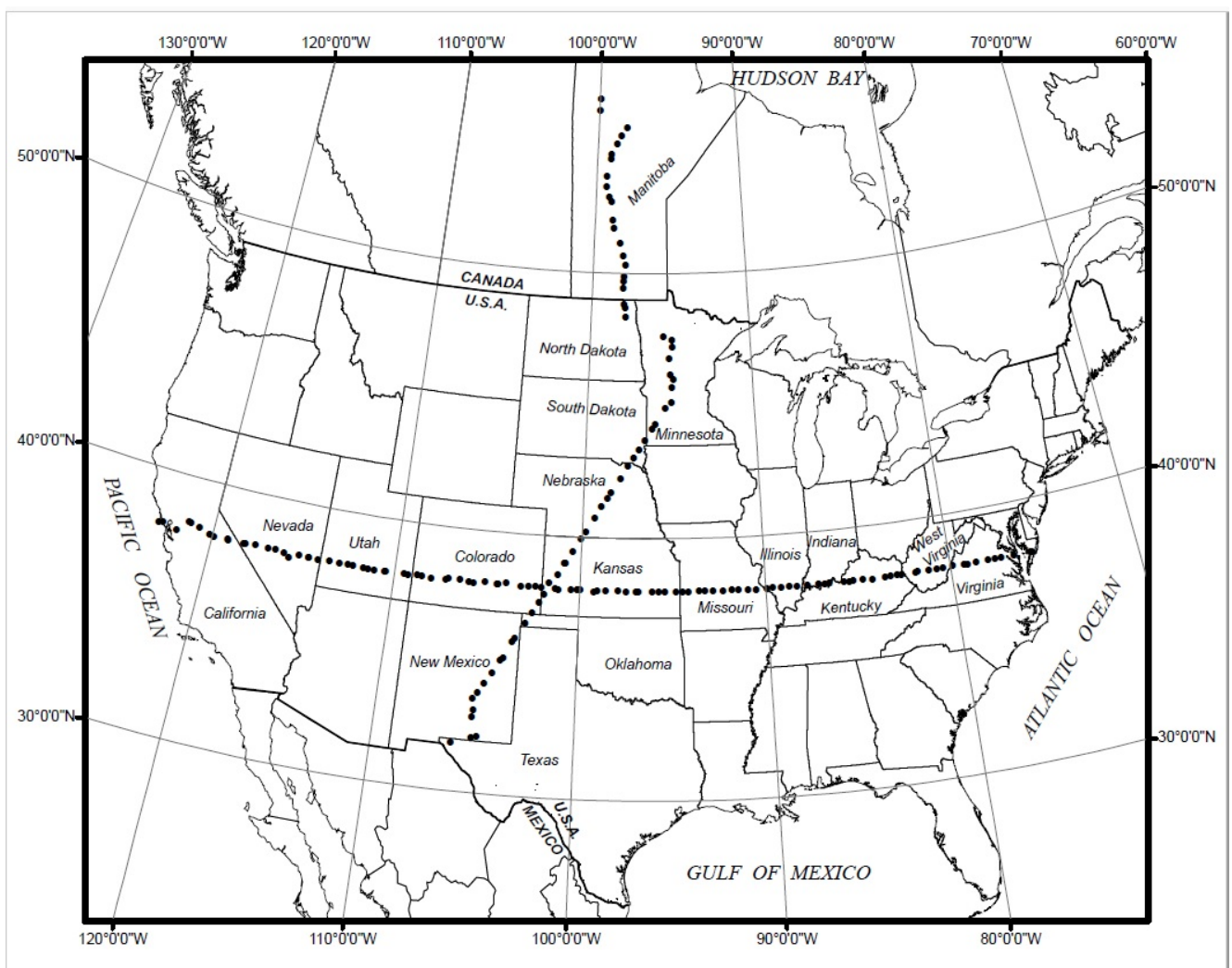

Figure 5

Location of soil sampling sites (small black dots) along two transects from the pilot studies for the USGS Soil Geochemical Landscapes of the Conterminous United States Project. Geochemistry and mineralogy from the west-to-east transect are discussed in the text.

In the Piedmont physiographic province (area 3 in Fig. 2), soil is developed on crystalline Precambrian and Paleozoic metamorphic and igneous rocks, mostly of granitic composition. Piedmont soil is deeply weathered and most feldspar has been altered to kaolinite (Fig. 8). The mineral gibbsite $\left[\mathrm{Al}(\mathrm{OH})_{3}\right]$ is an end-product of intense chemical weathering in areas of high rainfall and warm temperatures (Kato, 1965; Vazquez, 1981; Huang et al., 2002). Figure 9 shows the distribution of gibbsite in the soil A horizon as a point-symbol map. This type of map is used because gibbsite was only detected in slightly more than 2 percent of the samples analyzed. All occurrences of this mineral in the conterminous USA correlate with high kaolinite concentrations as seen by comparing Figures 8 and 9. Gibbsite is detected in soil from the
Piedmont (area 3 in Fig. 2) where intense weathering has modified kaolinite to gibbsite by loss of silica. In the north-western USA, the extreme climate variability from the coast across the Cascade Range and Sierra Nevada Mountains forms a very sharp precipitation gradient (Fig. 3) so that the gradual changes in soil mineralogy and chemistry observed in the eastern half of the United States are compressed along this much steeper gradient. These changes are expressed as lower feldspar and higher clay concentration, especially kaolinite, in the higher precipitation areas near the coast. As in the Piedmont, the intensity of weathering has been sufficient in some areas along the north-west coast to produce extremely aluminous soil marked by the appearance of gibbsite (Fig. 9). 


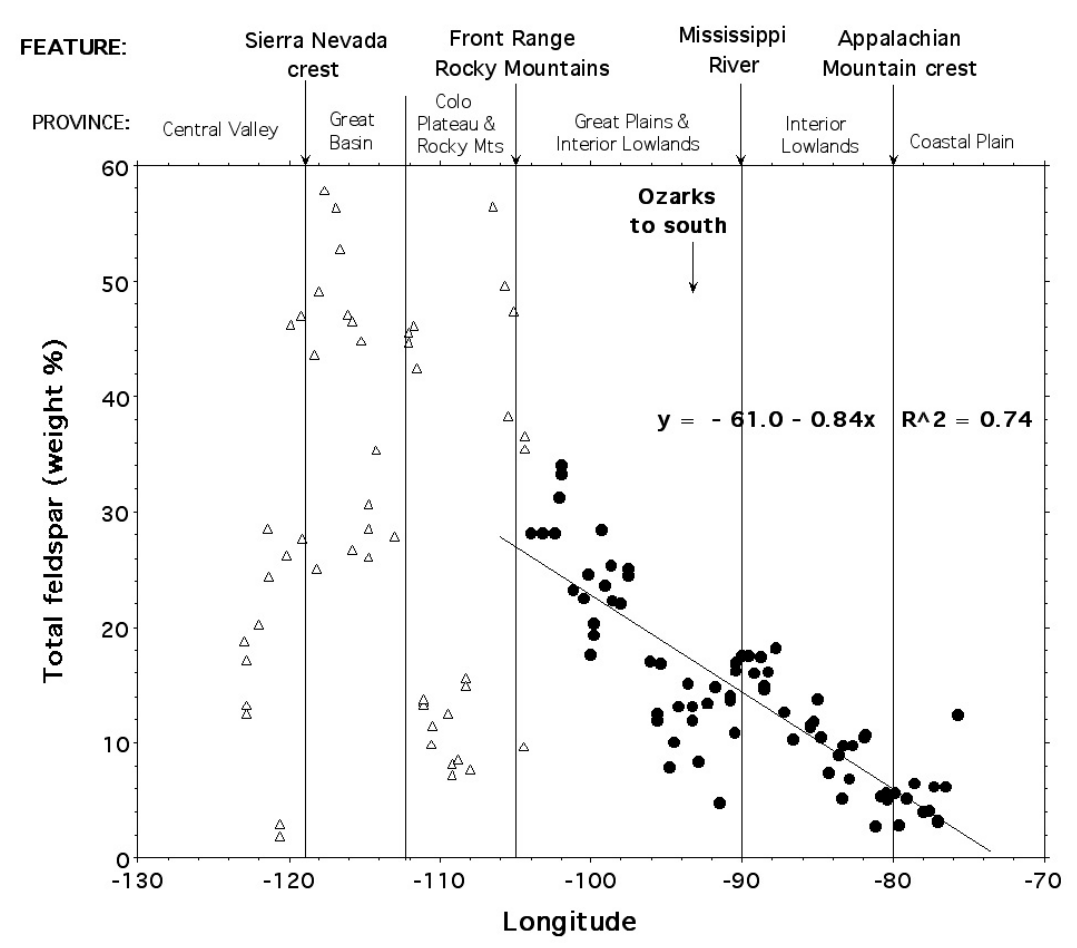

Figure 6

Weight percent total feldspar plotted against longitude for the west-to-east transect shown in Fig. 5 (from Eberl and Smith, 2009). Note the linear trend of decreasing feldspar concentration from approximately $-104^{\circ}$ longitude to the easternmost sample as shown by the solid circles.

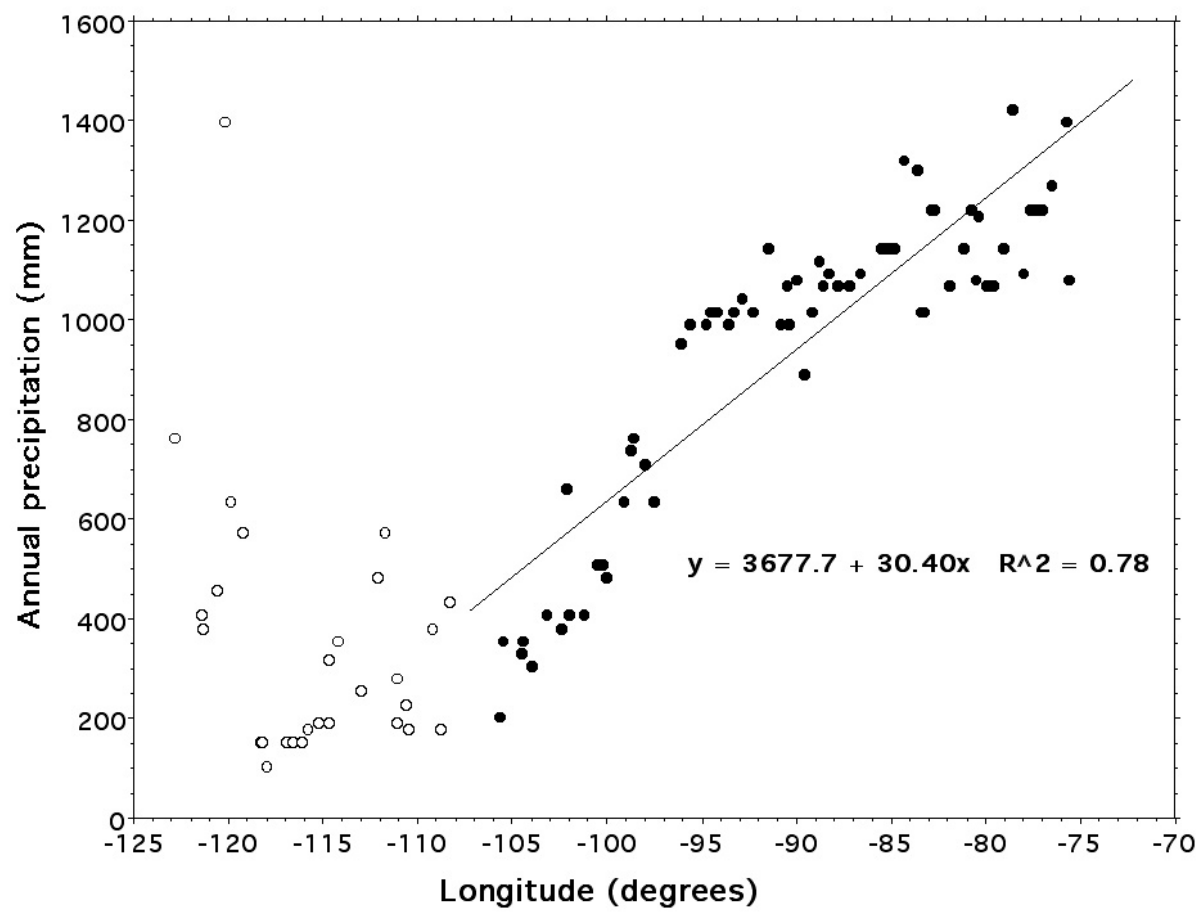

Figure 7

Average annual precipitation plotted against longitude for the west-to-east transect shown in Fig. 5 (from Eberl and Smith, 2009). Note the linear trend of increasing average annual precipitation from approximately $-105^{\circ}$ longitude to the easternmost sample as shown by

the solid circles. 


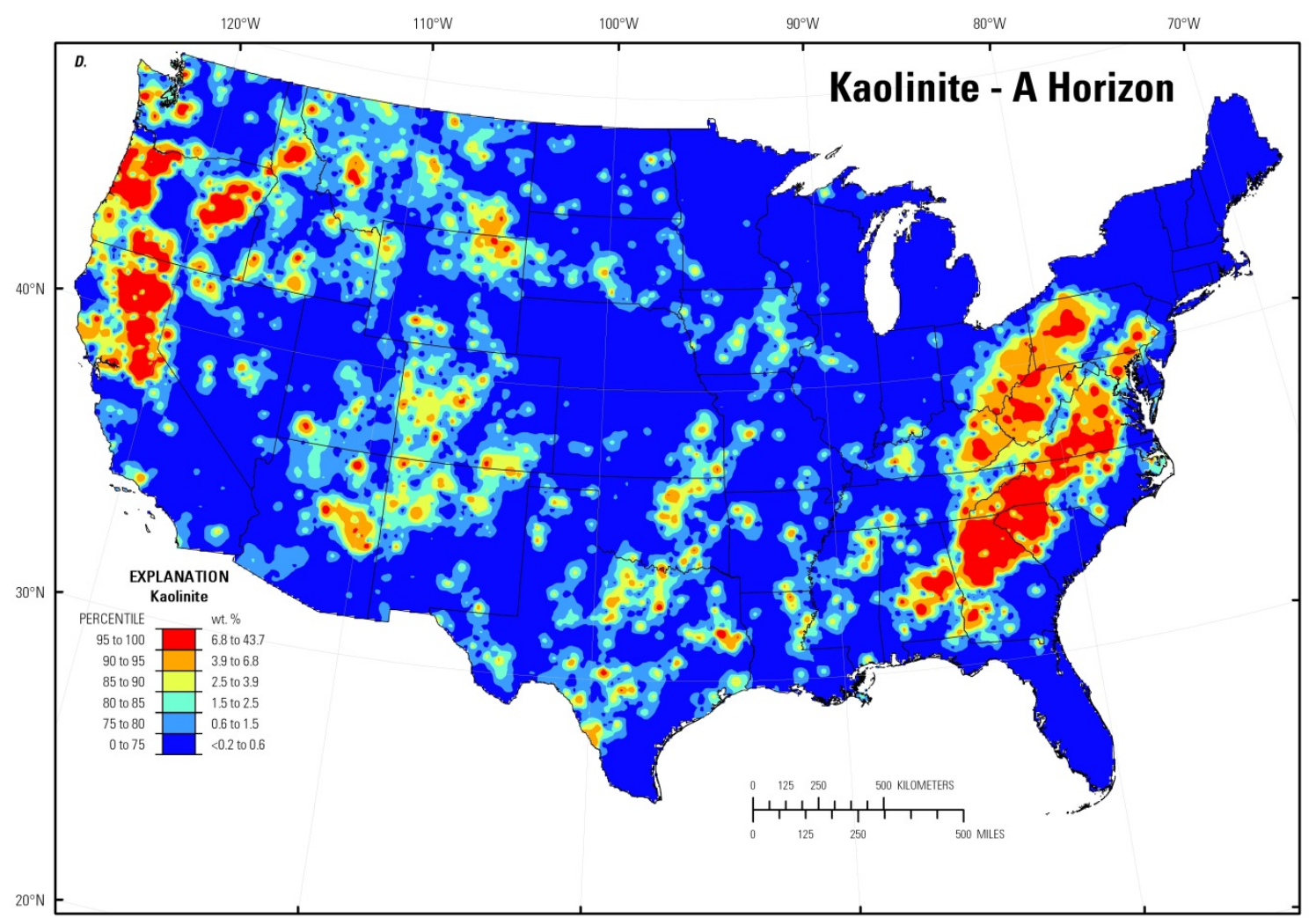

Figure 8

Map showing the distribution of kaolinite in the soil A horizon, conterminous United States (from Smith et al., 2014).

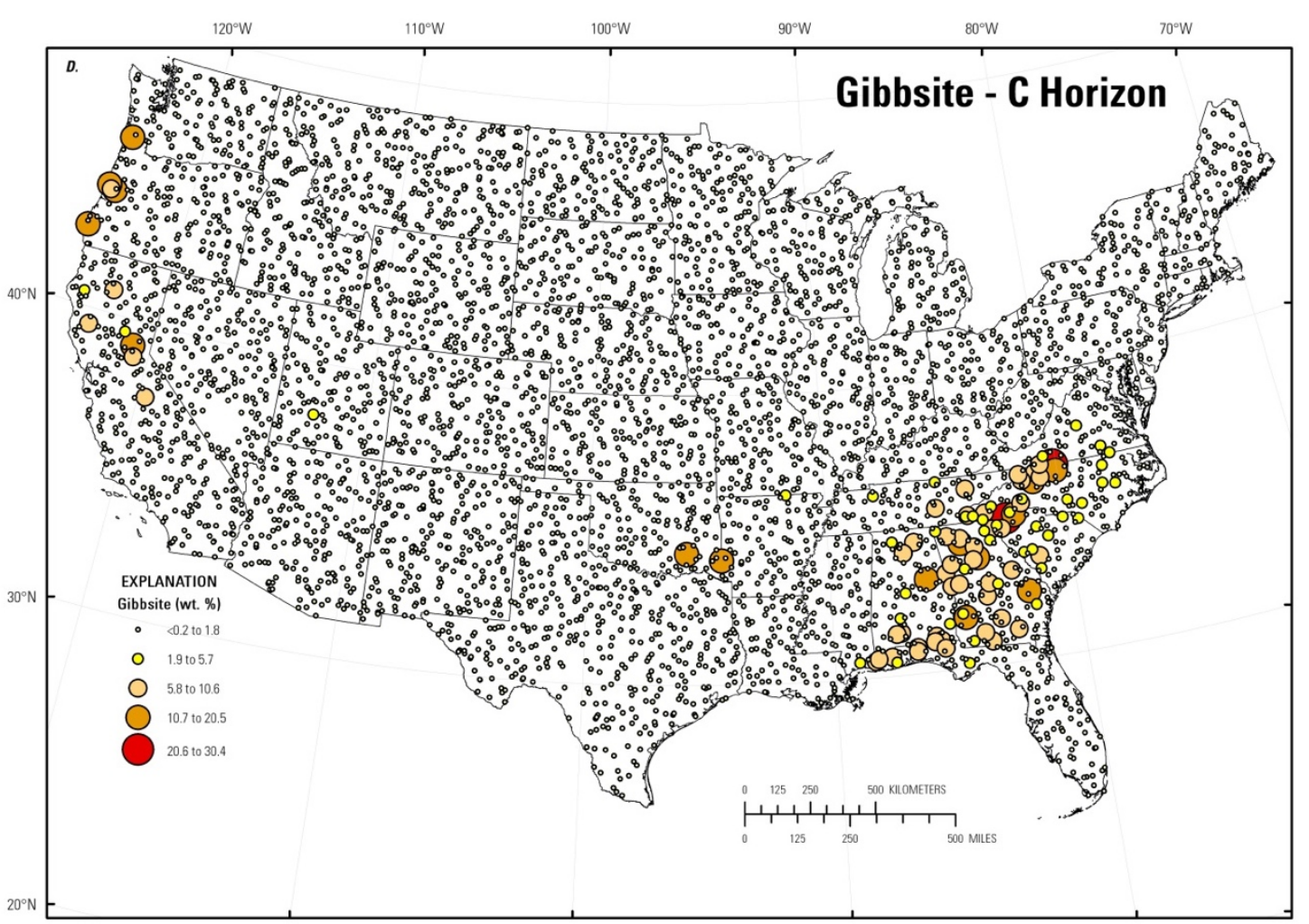

Figure 9

Map showing the distribution of gibbsite in the soil A horizon, conterminous United States (from Smith et al., 2014). Note that 4651 samples $(97.4 \%)$ had gibbsite concentrations below the detection limit of $0.2 \mathrm{wt} \%$. The concentration ranges for the classes shown in the legend were determined by visual inspection of the data distribution. 
This transformation of feldspar to kaolinite and then to gibbsite in soil is observed not only on the mineralogical maps, but also on the geochemical maps where the patterns portray the leaching of nearly all major and trace elements present in the feldspar structure. Prime examples are the major elements $\mathrm{K}$ and $\mathrm{Na}$ (Figs. 10 and 11) and the trace element $\mathrm{Rb}$ (Fig. 12), which often replaces $\mathrm{K}$ in potassium feldspars. All three of these elements become successively depleted in soil from west to east, producing a map pattern similar to that observed for total feldspar (Fig. 4). The area of feldspar-depleted soil, accompanied by low concentrations of $\mathrm{K}, \mathrm{Na}$, and $\mathrm{Rb}$, is of generally low-to-moderate relief, so that long-term weathering under humid conditions and low erosion rates forms large areas of very mature saprolitic soil, depleted in most easily leached elements. Although the Piedmont has complex bedrock geology providing highly variable soil parent materials, the effect of this parent material's compositional variability is overprinted by the effects of intense chemical weathering.

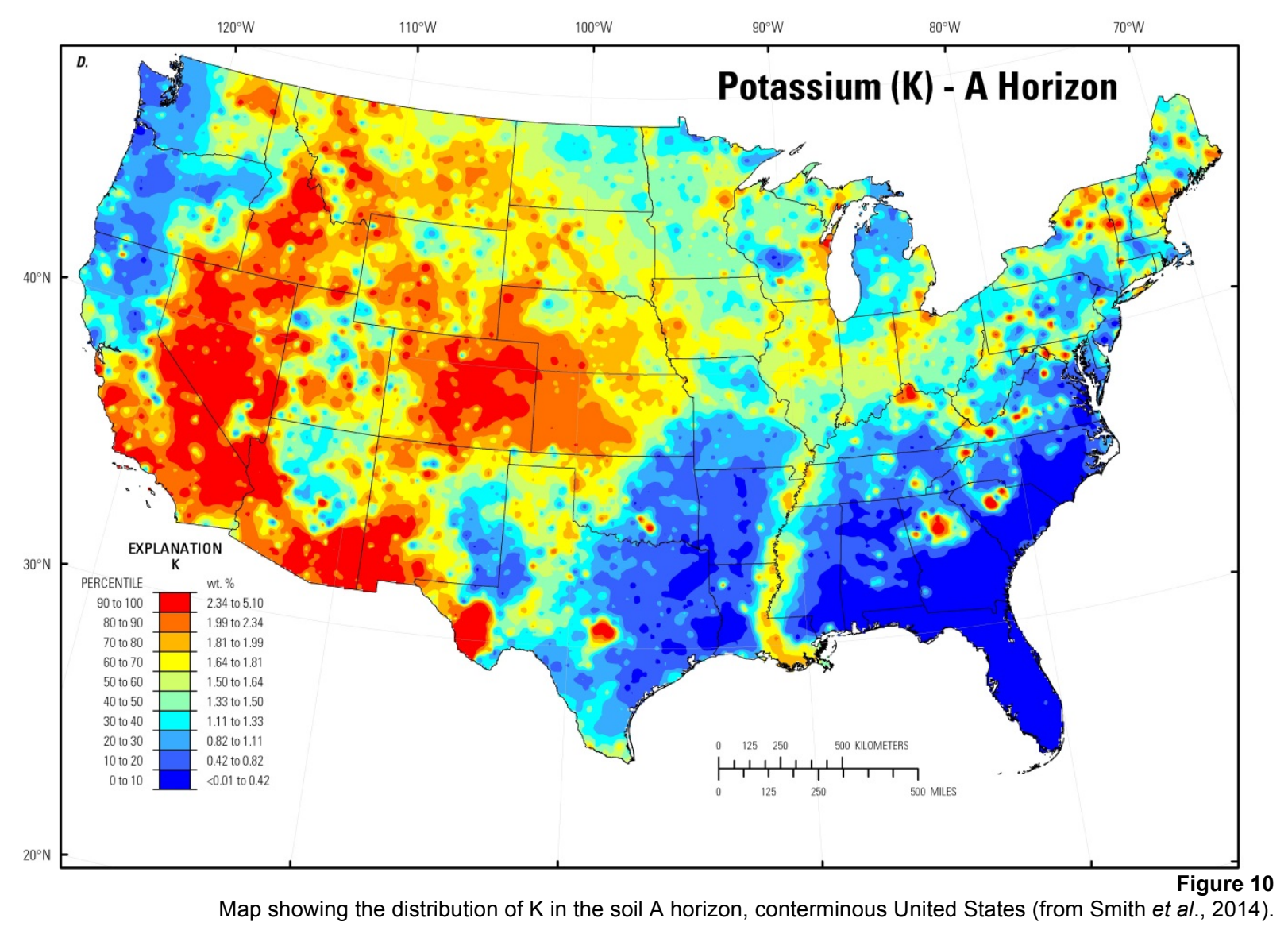

The importance of climate versus parent material is revealed in the mineralogy and chemistry of soil in the Piedmont and adjacent Coastal Plain (area 2 on Fig. 2). Soil types in both regions are developed under similar climate regimes, but with strongly contrasting parent materials. Soil in the Piedmont typically has high secondary kaolinite concentrations, whereas soil in the Coastal Plain is dominated by primary quartz (Fig. 13).

The extremely important role played by quartz $\left(\mathrm{SiO}_{2}\right)$ in determining soil geochemistry must be recognized when interpreting element patterns observed on geochemical maps. Quartz in the conterminous USA varies in concentration from $<0.2$ to $99.4 \mathrm{wt} \%$ in the soil $\mathrm{C}$ horizon (Smith et al., 2013) and is, on average, the most abundant mineral in soil with a median concentration of $44.1 \mathrm{wt} \%$ in the soil $\mathrm{C}$ horizon. Quartz has a structure that does not allow much incorporation of trace elements and contains essentially no elements other than silicon and oxygen. The high purity of quartz means that increasing concentration of this mineral will dilute the concentration of other minerals that carry most of the elements that were determined in this study. Twenty elements from the soil $\mathrm{C}$ horizon (Al, Ga, $\mathrm{Na}, \mathrm{Sc}, \mathrm{Fe}, \mathrm{Mg}, \mathrm{V}, \mathrm{Be}, \mathrm{Ba}, \mathrm{Sr}, \mathrm{Y}, \mathrm{K}, \mathrm{P}, \mathrm{Co}, \mathrm{Ca}, \mathrm{Tl}$ 


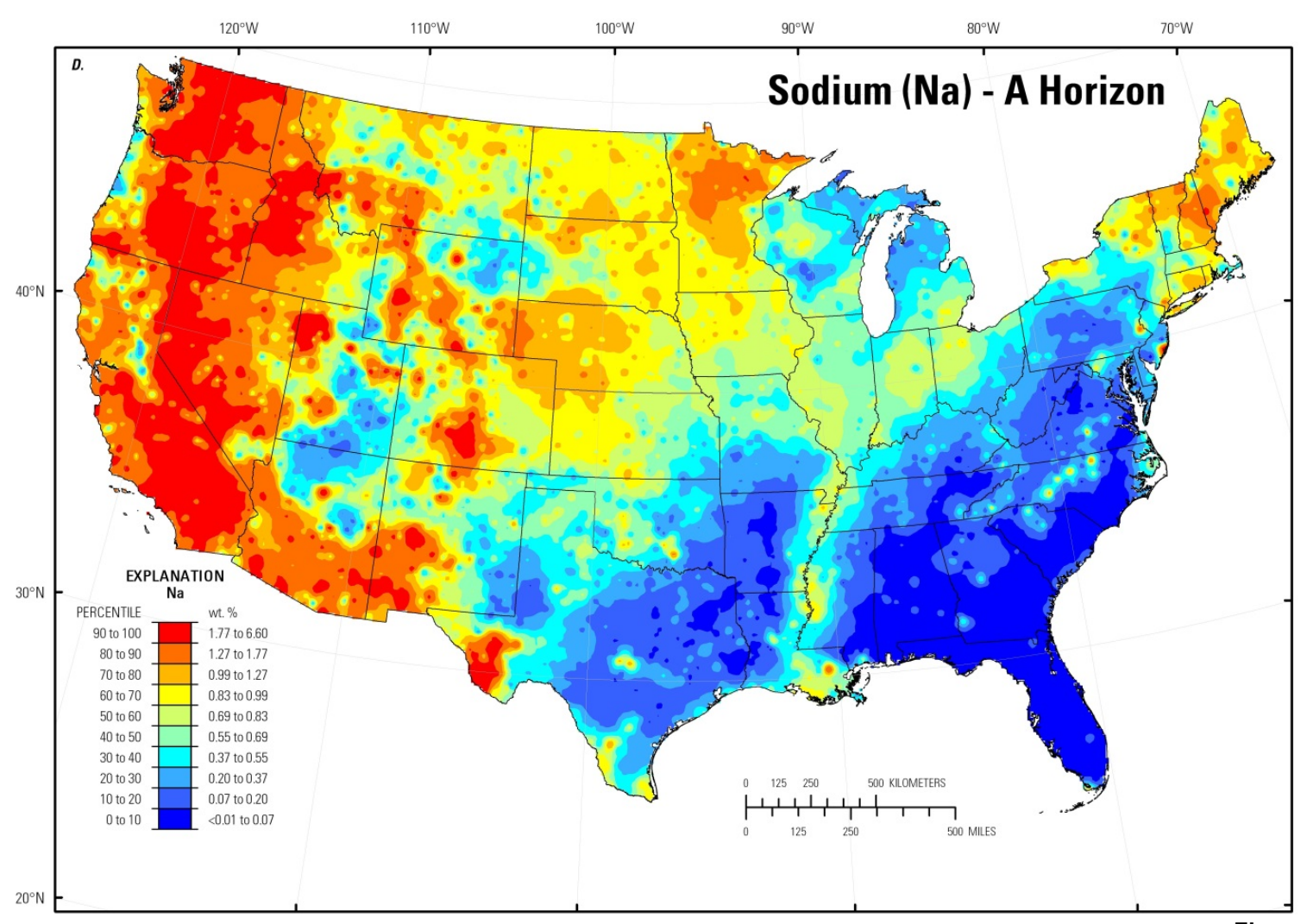

Figure 11

Map showing the distribution of $\mathrm{Na}$ in the soil A horizon, conterminous United States (from Smith et al., 2014).

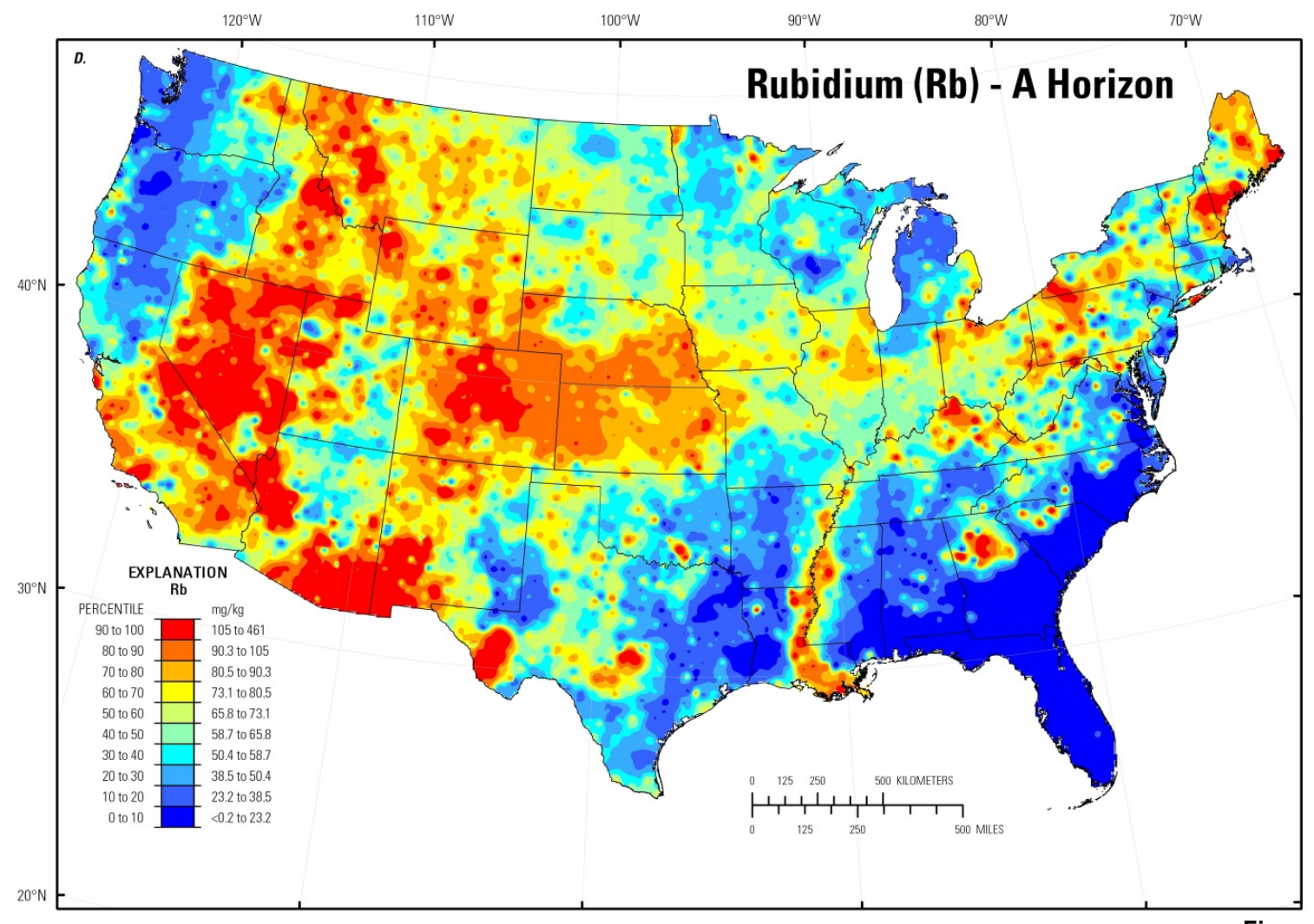

Figure 12

Map showing the distribution of $\mathrm{Rb}$ in the soil A horizon, conterminous United States (from Smith et al., 2014). 


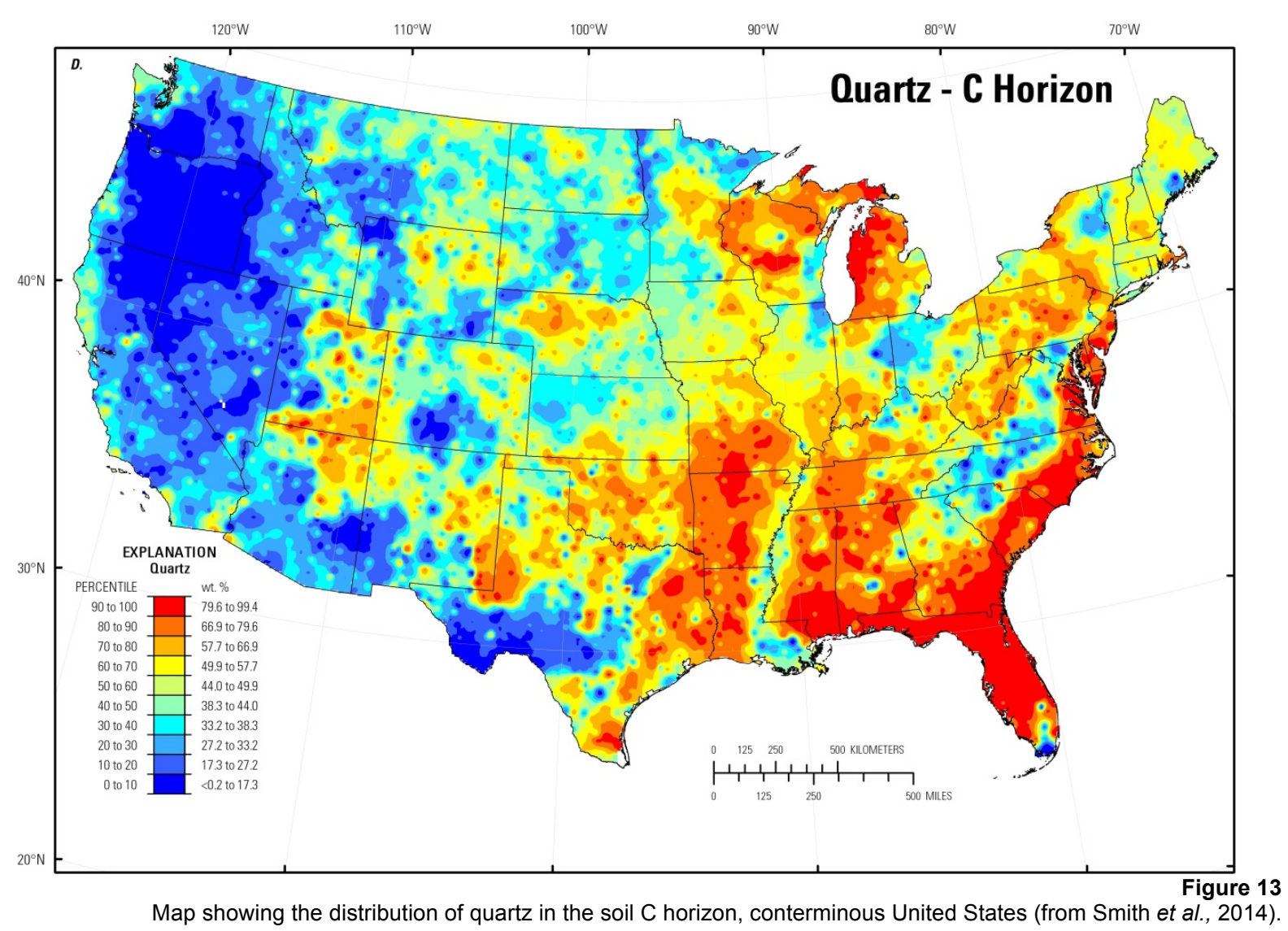

$\mathrm{Li}, \mathrm{Rb}, \mathrm{Nb}$, and $\mathrm{Zn}$, listed in order from highest to lowest negative correlations) show significant negative correlation with quartz concentration, indicating that this inverse quartz relationship will necessarily appear as part of their distribution patterns on continental-scale geochemical maps (Woodruff et al., 2015). The relationship can be seen by comparing the distribution of $\mathrm{Na}$ (Fig. 11) and $\mathrm{Rb}$ (Fig. 12) with that of quartz (Fig. 13). The observed spatial distribution of these elements is,

\section{SUMMARY}

The origin of global- and continental-scale geochemical mapping can be traced back to the 1980s. This type of geochemical mapping, utilizing very low-density sampling ( 1 site per 1000 to $10,000 \mathrm{~km}^{2}$ ) to cover millions of square kilometers of the Earth's land surface, produces robust map patterns (Smith and Reimann, 2008) that are indicative of broad-scale processes that act, either currently or in the geological past, at the scale of the mapping. These processes are related to many factors including climate, weathering, geochemical and mineralogical composition of the original soil parent material, continental-scale glaciation, topography, regionalscale alteration and mineralization, and in some cases, human activity. Interpretation of at least in part, controlled by processes that concentrate or dilute quartz rather than processes related to the geochemical behavior of these elements themselves. Interpretation of geochemical maps, particularly those based on global- and continental-scale data, must always recognize that the cause of spatial variation in element concentration may be related to this 'quartz dilution effect' (Bern, 2009).

geochemical maps generated from such lowsampling density data must recognize the scale of the processes that influence the observed map patterns.

The past 15 years have seen the completion of global-scale geochemical mapping projects in several parts of the world, including Australia, China, Europe, India, Mexico, and the United States of America. These surveys provide geochemical coverage for approximately $24 \%$ of the Earth's land surface. The datasets are currently being used for a wide variety of purposes including environmental regulation, exploration for mineral resources, public health, food safety, and understanding the effects of global climate change. It is hoped that those datasets that are not 
currently available to the public will soon become so, and that future continental-scale geochemical surveys will allow open access to their results to benefit humanity as a whole. The establishment in 2016 of the IUGS Commission on Global Geochemical Baselines and the UNESCO

\section{REFERENCES ${ }^{1}$}

Ali, S.H., Giurco, D., Arndt, N., Nickless, E., Brown, G., Demetriades, A., Durrheim, R., Enriquez, M.A. Kinnaird, J., Littleboy, A., Meinert, L.D., Oberhänsli, R., Salem, J., Schodde, R., Schneider, G., Vidal, O., Yakovleva, N., 2017. Mineral supply for sustainable development requires resource governance. Nature (Perspectives) 543(7645), 367372. http://dx.doi.org/10.1038/nature21359; Supplementary information: http://www.nature.com/nature/journal/v543/n7645/ abs/nature21359.html\#supplementary-information.

Bern, C.R., 2009. Soil chemistry in lithologically diverse datasets: The quartz dilution effect. Applied Geochemistry 24, 1429-1437.

Birke, M., Reimann, C., Oorts, K., Rauch, U., Demetriades, A., Dinelli, E., Ladenberger, A., Halamić, J.,Gosar, J., Jähne-Klingsberg, F., the GEMAS Project Team, 2016. Use of GEMAS data for risk assessment of cadmium in European agricultural and grazing land soil under the REACH Regulation. Applied Geochemistry 74, 109-121.

Boerngen, J.G., Shacklette, H.T., 1981. Chemical Analyses of Soils and Other Surficial Materials of theConterminous United States. U.S. Geological Survey Open-File Report 81-197, 143 pp., https://pubs.usgs.gov/of/1981/0197/report.pdf.

Bølviken, B., Bergstrøm, J., Bjørklund, A., Kontio, M., Ottesen, R.T., Steenfelt, A., Volden, T., 1986. Geochemical atlas of northern Fennoscandia. Scale: 1:4,000,000. Geological Surveys of Finland, Greenland, Norway and Sweden, Espoo, 19 p., 155 map sheets.

Bølviken, B., Demetriades, A., Hindel, A., Locutura, J., O'Connor, P., Ottesen, R.T., Plant, J., Ridgway, J., Salminen, R., Salpeteur, I., Schermann, O., Volden, T. (Editors), 1990. Geochemical Mapping of Western Europe towards the Year 2000. Project Proposal. Western European Geological Surveys (WEGS). Geological Survey of Norway, Trondheim, NGU Report 90-106, 12 pages and 9 appendices;

http://www.ngu.no/upload/Publikasjoner/Rapporter/ 1990/90 106.pdf.

Bølviken, B., Bogen, B., Demetriades, A., De Vos, W., Ebbing, J., Hindel, R., Ottesen, R.T., Salminen, R., Schermann, O., Swennen, R., 1993. Geochemical Mapping of Western Europe towards the Year 2000. Final Report of the Working Group on Regional Geochemical Mapping 1986-93. Forum of
International Centre for Global-Scale Geochemistry is a recognition of the importance of this activity and provides hope for continued progress in mapping the geochemistry of the Earth's land surface at a global scale.

European Geological Surveys (FOREGS). Geological Survey of Norway, Trondheim, NGU Report 93.092, 18 pp. and 6 appendices; http://www.ngu.no/upload/Publikasjoner/Rapporter/ 1993/93_092.pdf.

Bølviken, B., Bogen, J., Demetriades, A., De Vos, W., Ebbing, J., Hindel, R., Langedal, M., Locutura, J., O'Connor, P., Ottesen, R.T., Pulkkinen, E., Salminen, R., Schermann, O., Swennen, R., Van der Sluys, J., Volden, T., 1996. Regional geochemical mapping of Western Europe towards the year 2000. Journal of Geochemical Exploration 56(2), 141-166.

Brantley, S.L., Goldhaber, M.B., Ragnarsdottir, K.V., 2007. Crossing disciplines and scales to understand the critical zone. Elements 3(5), 307-314.

Caritat, P. de, Cooper, M., 2011. National Geochemical Survey of Australia: The Geochemical Atlas of Australia. Geoscience Australia Record 2011/20, $557 \quad$ pp. $\quad(2$ Volumes $)$, http://www.ga.gov.au/about/projects/resources/nati onal-geochemical-survey.

Caritat, P. de, Cooper, M., 2016. A continental-scale geochemical atlas for resource exploration and environmental management: the National Geochemical Survey of Australia. Geochemistry: Exploration, Environment, Analysis 16, 3-13.

Caritat, P. de, Grunsky, E.C., 2013. Defining element associations and inferring geological processes from total element concentrations in Australian catchment outlet sediments: Multivariate analysis of continental-scale geochemical data. Applied Geochemistry 33, 104-126.

Caritat, P. de, Main, P.T., Grunsky, E.C., Mann, A., 2017. Recognition of geochemical footprints of mineral systems in the regolith at regional to continental scales. Australian Journal of Earth Sciences 64, 1033-1043.

Caritat, P. de, Reimann, C., Smith, D.B., Wang, X., 2018. Chemical elements in the environment: multi element geochemical datasets from continental- to national-scale surveys on four continents. Applied Geochemistry 89, 150-159.

CDC (Centers for Disease Control and Prevention), 2009. Fourth National Report on Human Exposure to Environmental Chemicals. Department of Health and Human Services, Centers for Disease Control and Prevention, Atlanta, GA, 519 pp.

\footnotetext{
${ }^{1}$ Note: All website links accessed on 30th April 2018 unless noted otherwise.
} 
Cracknell, M.J., Caritat, P. de, 2017. Catchment-based gold prospectivity analysis combining geochemical, geophysical and geological data across northern Australia. Geochemistry: Exploration, Environment, Analysis 17, 204-216.

Darnley, A.G., 1995. International geochemical mapping - a review. Journal of Geochemical Exploration 55, 5-10.

Darnley, A.G., 1997. A global geochemical reference network: the foundation for geochemical baselines. Journal of Geochemical Exploration 60, 1-5.

Darnley, A.G., Björklund, A., Bølviken, B., Gustavsson, N., Koval, P.V., Plant, J.A., Steenfelt, A., Tauchid, M., Xuejing, X., Garrett, R.G., Hall, G.E.M., 1995. A global geochemical database for environmental and resource management. Final report of IGCP Project 259. Earth Sciences, 19, UNESCO Publishing, Paris, 122 pp., http:/www.globalgeochemicalbaselines.eu/wpcontent/uploads/2012/07/Blue_Book_GGD_IGCP2 59.pdf.

Demetriades, A., Ottesen, R.T., Locutura, J. (Editors), 1990. Geochemical mapping of Western Europe towards the Year 2000. Pilot Project Report. Western European Geological Surveys, Geological Survey of Norway, Trondheim, Open File Report $90-105,9$ pages and 10 appendices; http://www.ngu.no/upload/Publikasjoner/Rapporter/ 1990/90_105.pdf.

De Vos, W., Tarvainen, T., Salminen, R., Reeder, S., De Vivo, B., Demetriades, A., Pirc, S., Batista, M.J., Marsina, K., Ottesen, R.T., O’Connor, P.J., Bidovec, M., Lima, A., Siewers, U., Smith, B., Taylor, H., Shaw, R., Salpeteur, I., Gregorauskiene, V., Halamic, J., Slaninka, I., Lax, K., Gravesen, P., Birke, M., Breward, N., Ander, E.L., Jordan, G., Duris, M., Klein, P., Locutura, J., Bel-lan, A., Pasieczna, A., Lis, J., Mazreku, A., Gilucis, A., Heitzmann, P., Klaver, G., Petersell, V., 2006. Geochemical Atlas of Europe. Part 2 Interpretation of Geochemical Maps, Additional Tables, Figures, Maps, and Related Publications. Geological Survey of Finland, Espoo, 692 pp., http://weppi.gtk.fi/publ/foregsatlas/.

Eberl, D.D., Smith, D.B., 2009. Mineralogy of soils from two continental-scale transects across the United States and Canada and its relation to soil geochemistry and climate. Applied Geochemistry 24, 1394-1404.

Fenneman, N.M., Johnson, D.W., 1946. Physical divisions of the United States: U.S. Geological Survey map prepared in cooperation with the Physiographic Commission, scale 1: 700,000 (reprinted in 1964), https://water.usgs.gov/GIS/meta data/usgswrd/XML/physio.xml.

Garrett, R.G., Reimann, C., Smith, D.B., Xie, X., 2008. From geochemical prospecting to international geochemical mapping: a historical overview. Geochemistry: Exploration, Environment, Analysis 8(3-4), 205-217.

Grunsky, E.C., Drew, L.J., Smith, D.B., 2018. Analysis of the United States portion of the North American
Soil Geochemical Landscapes Project-A compositional framework approach. In: Daya Sagar, B.S., Cheng, Q., Agterberg, F., Eds., Handbook of Mathematical Geosciences-Fifty Years of IAMG. Springer, Cham, p. 313-346, https://www.springer.com/us/book/9783319789989 accessed on 15th July 2018.

Gustavsson, N., Bølviken, B., Smith, D.B., Severson, R.C., 2001. Geochemical Landscapes of the Conterminous United States: New Map Presentations for 22 Elements. U.S. Geological Survey Professional Paper 1648, 38 pp., https://pubs.usgs.gov/pp/p1648/p1648.pdf.

Hester, R.E., Harrison, R.M. (Eds), 2006. Chemicals in the Environment: Assessing and Managing Risk. Issues in Environmental Science and Technology, vol. 22. The Royal Society of Chemistry, Cambridge, 158 pp.

Huang, P.M., Wang, M.K., Kampf, N., Schulze, D.G., 2002. Aluminum hydroxides. In: Dixon, J.B., Schulze, D.G. (Eds). Soil Mineralogy with Environmental Applications. Soil Science Society of America, Madison, 261-289.

Kato, Y., 1965. Mineralogical study of weathering products of granodiorite at Shinshiro City (VI). Soil Science and Plant Nutrition, 11(3), 25-30. https://www.tandfonline.com/doi/pdf/10.1080/0038 0768.1965 .10431160$.

Lerner, S., 2012, Sacrifice zones: The front lines of toxic chemical exposure in the United States. MIT Press, Cambridge, MA, 368 pp.

Nickless, E., Ali, S., Arndt, N., Brown, G., Demetriades, A., Durrheim, R., Enriquez M.A., Giurco, D., Kinnaird, J., Littleboy, A., Masotti, F., Meinert, L., Nyanganyura, D., Oberhänsli, R., Salem, J., Schneider, G., Yakovleva., N., 2015. Resourcing Future Generations: A Global Effort to Meet The World's Future Needs Head-on. International Union of Geological Sciences, $76 \mathrm{pp}$. http://iugs.org/uploads/RFG\%20Report-sm.pdf.

Nriagu, J.O., 1988. A silent epidemic of environmental metal poisoning? Environmental Pollution 50, 139161.

Ottesen, R.T., Bogen, J., Bølviken, B., Volden, T., 1989. Overbank sediment: a representative sample medium for regional geochemical mapping. In: Jenness, S.E. (Ed.), Geochemical Exploration 1987. Journal of Geochemical Exploration 32 (1-3), 257277.

Plant, J.A., Klaver, G., Locutura, J., Salminen, R., Vrana, K., Fordyce, F., 1996. Forum of European Geological Surveys (FOREGS), Geochemistry Task Group 1994-1996 Report. A contribution to IUGS Continental Geochemical Baselines. British Geological Survey, Keyworth, Nottingham, U.K., BGS Technical Report WP/95/14, 52 pp., http://nora.nerc.ac.uk/19012/1/WP95014.pdf.

Plant, J., Smith, D., Smith, B., Williams, L., 2001. Environmental geochemistry at the global scale. Applied Geochemistry 16, 1291-1308.

Plant, J., Smith, D., Smith, B., Reeder, S., 2003. Environmental geochemistry on a global scale. In: 
Skinner, H.C.W., Berger, A.R. (Eds), Geology and Health: Closing the Gap. Oxford University Press, New York, p. 129-134.

Plant, J.A., Korre, A., Reeder, S., Smith, B., Voulvoulis, N., 2005. Chemicals in the environment: implications for global sustainability. Applied Earth Science (Transactions of the Institutes of Mining and Metallurgy: Section B) 114, 65-97.

Rapant, S., Salminen, R., Tarvainen, T., Krčmová, K., Cvečková, V., 2008. Application of a risk assessment method to Europe-wide geochemical baseline data. Geochemistry: Exploration, Environment, Analysis 8(3-4), 291-299.

Reeder, S., 2007. Global geochemical baselines. Episodes 30, 69-72.

Reeder, S., Plant, J.A., Smith D.B., 2002. IUGS/IAGC Working Group on Global Geochemical Baselines. Episodes 25, 286-287.

Reimann, C., Caritat, P. de., 2005. Distinguishing between natural and anthropogenic sources for elements in the environment: regional geochemical surveys versus enrichment factors. Science of the Total Environment 337, 91-107.

Reimann, C., Melezhik, V., Niskavaara, H., 2007. Low-density regional geochemical mapping of gold and palladium highlighting the exploration potential of northernmost Europe. Economic Geology 102, 327-334.

Reimann, C., Birke, M., Demetriades, A., Filzmoser, P., O'Connor, P. (Editors), 2014a. Chemistry of Europe's agricultural soils - Part A: Methodology and interpretation of the GEMAS data set. Geologisches Jahrbuch (Reihe B 102), Schweizerbarth, Hannover, 528 pp., http://www.schweizerbart.de/publications/detail/isb n/9783510968466.

Reimann, C., Birke, M., Demetriades, A., Filzmoser, P., O'Connor, P. (Editors), 2014b. Chemistry of Europe's agricultural soils - Part B: General background information and further analysis of the GEMAS data set. Geologisches Jahrbuch (Reihe B 103), Schweizerbarth, Hannover, 352 pp., https://www.schweizerbart.de/publications/detail/is bn/9783510968473/Geologisches_Jahrbuc\%20h_R eihe_B_Heft_B103_Chemistry. Parts A \& B: http://www.schweizerbart.de/publications/list/series /geoljbb.

Reimann, C., Caritat, P. de, 2017. Establishing geochemical background variation and threshold values for 59 elements in Australian surface soil. Science of the Total Environment 578, 633-648.

Salminen, R., Tarvainen, T., Demetriades, A., Duris, M., Fordyce, F.M., Gregorauskiene, V., Kahelin, H., Kivisilla, J., Klaver, G., Klein, P., Larson, J.O., Lis, J., Locutura, J., Marsina, K., Mjartanova, H., Mouvet, C., O’Connor, P., Odor, L., Ottonello, G., Paukola, T., Plant, J.A., Reimann, C., Schermann, O., Siewers, U., Steenfelt, A., Van Der Sluys, J., Williams, L., 1998. FOREGS Geochemical Mapping Field Manual. Geological Survey of Finland, Espoo, Guide 47, 36 pp., http://tupa.gtk.fi/julkaisu/opas/op_047.pdf.
Salminen, R., Batista, M.J., Bidovec, M., Demetriades, A., De Vivo, B., De Vos, W., Duris, M., Gilucis, A., Gregorauskiene, V., Halamic, J., Heitzmann, P., Lima, A., Jordan, G., Klaver, G., Klein, P., Lis, J., Locutura, J., Marsina, K., Mazreku, A., O’Connor, P.J., Olsson, S.Å., Ottesen, R.T., Petersell, V., Plant, J.A., Reeder, S., Salpeteur, I., Sandström, H., Siewers, U., Steenfelt, A., Tarvainen, T., 2005. FOREGS Geochemical Atlas of Europe, Part 1: Background Information, Methodology and Maps. Geological Survey of Finland, Espoo, 526 pp., http://weppi.gtk.fi/publ/foregsatlas/.

Shacklette, H.T., Boerngen, J.G., 1984. Element concentrations in soils and other surficial materials of the conterminous United States. U.S. Geological Survey Professional Paper 1270, 105 pp., https://pubs.usgs.gov/pp/1270/pdf/PP1270_508.pdf.

Skinner, H.C.W., Berger, A.R. (Eds), 2003. Geology and Health: Closing the Gap. Ford University Press, New York, 179 pp.

Smith, D.B., Reimann, C., 2008. Low-density geochemical mapping and the robustness of geochemical patterns. In: Reimann, C., Smith, D.B. (Guest editors). Thematic set in honour of Arthur G. Darnley (1930-2006). Geochemistry: Exploration, Environment, Analysis 8(3-4), 219227.

Smith, D.B., Woodruff, L.G., O’Leary, R.M., Cannon, W.F., Garrett, R.G., Kilburn, J.E., Goldhaber, M.B., 2009. Pilot studies for the North American Soil Geochemical Landscapes Project-Site selection, sampling protocols, analytical methods, and quality control protocols. Applied Geochemistry 24, 13571368.

Smith, D.B., Wang, X., Reeder, S., Demetriades, A., 2012. The IUGS/IAGC Task Group on Global Geochemical Baselines. Earth Science Frontiers 19(3), 1-6.

Smith, D.B., Smith S.M., Horton, J.D., 2013a. History and evaluation of national-scale geochemical data sets for the United States. Geoscience Frontiers 4, 167-183.

Smith, D.B., Cannon, W.F., Woodruff, L.G., Solano, F., Kilburn, J.E., Fey, D.L., 2013b. Geochemical and mineralogical data for soils of the conterminous United States. U.S. Geological Survey Data Series 801, 19 pp., http://pubs.usgs.gov/ds/801/.

Smith, D.B., Cannon W.F., Woodruff, L.G., Solano, F., Ellefsen, K.J., 2014. Geochemical and mineralogical maps for soils of the conterminous United States. U.S. Geological Survey Open-File Report 2014-1082, $386 \quad$ pp., http://pubs.usgs.gov/of/2014/1082/.

Smith, D.B., Wang, X., Demetriades, A., Caritat, P. de, 2017. Global-scale geochemical baselines mapping: Steps forward in 2016. Explore 174, 19-21.

van Gaans, P.F.M., Spijker, J., Vriend, S.P., de Jong, J.N., 2007. Patterns in soil quality: Natural geochemical variability versus anthropogenic impact in soils of Zeeland, The Netherlands. International Journal of Geographical Information Science 21, 569-587. 
Vazquez, F.M., 1981. Formation of gibbsite in soils and saprolites of temperate-humid zones. Clay Minerals, 16, 43-52. http://www.minersoc.org/pages /Archive-CM/Volume 16/16-1-43.pdf.

Wang X., Xie X., Zhang B., Zhang Q., Chi Q., Hou Q., $\mathrm{Xu}$ S., Zhang B., 2010. China Geochemical Probe: Making "Chemical Earth". Acta Geologica Sinica 84(6), 854-864 (in Chinese with English abstract).

Wang, X., CGB Sampling Team, 2015. China geochemical baselines: Sampling methodology. In: Demetriades, A., Birke, M., Albanese, S., Schoeters, I., De Vivo, B. (Guest Editors), Special Issue: Continental, regional and local scale geochemical mapping. Journal of Geochemical Exploration 148, 25-39.

Woodruff, L., Cannon, W.F., Smith, D.B., Solano, F., 2015. The distribution of selected elements and minerals in soil of the conterminous United States. In: Demetriades, A., Birke, M., Albanese, S., Schoeters, I., De Vivo, B. (Guest Editors). Special
Issue: Continental, regional and local scale geochemical mapping. Journal of Geochemical Exploration 154, 49-60.

Xie, X., Cheng, H., 1997. The suitability of floodplain sediment as a global sampling medium: evidence from China. In: Taylor, G.F., Davy, R. (Editors), Geochemical Exploration 1995, II. Special Issue, Journal Geochemical Exploration 58(1), 51-62.

Yao, W., Xie, X., Zhao, P., Bai, J., 2014. Global scale geochemical mapping program-Contributions from China. Journal of Geochemical Exploration 139, 9-20.

Zhang, Q., Bai, J., Wang, Y., 2012. Analytical scheme and quality monitoring system for China Geochemical Baselines. Earth Science Frontiers 19(3), 33-42 (in Chinese with English abstract).

Zoback, M.L., 2001. Grand challenges in earth and environmental sciences - Science, stewardship, and service for the twenty-first century. GSA Today 11(12), 41-47. 